\title{
Alzheimer's disease: relevant molecular and physiopathological events affecting amyloid- $\beta$ brain balance and the putative role of PPARs
}

\author{
Juan M. Zolezzi ${ }^{1}$ *, Sussy Bastías-Candia ${ }^{1}$, Manuel J. Santos ${ }^{2}$ and Nibaldo C. Inestrosa ${ }^{3,4,5}$ * \\ ${ }^{1}$ Laboratorio de Biología Celular y Molecular, Departamento de Biología, Facultad de Ciencias, Universidad de Tarapacá, Arica, Chile \\ ${ }^{2}$ Departamento de Biología Celular y Molecular, Facultad de Ciencias Biológicas, Pontificia Universidad Católica de Chile, Santiago, Chile \\ ${ }^{3}$ Centro de Envejecimiento y Regeneración (CARE), Departamento de Biología Celular y Molecular, Facultad de Ciencias Biológicas, Pontificia Universidad \\ Católica de Chile, Santiago, Chile \\ ${ }^{4}$ Centre for Healthy Brain Ageing, School of Psychiatry, Faculty of Medicine, University of New South Wales, Sydney, NSW, Australia \\ ${ }^{5}$ Centro de Excelencia en Biomedicina de Magallanes (CEBIMA), Universidad de Magallanes, Punta Arenas, Chile
}

\section{Edited by:}

Robert Marr, Rosalind Franklin

University of Medicine and Science,

USA

Reviewed by:

Aurel Popa-Wagner, Clinic of

Psychiatry, Germany

Eliezer Masliah, University of

California, San Diego, USA

\section{*Correspondence:}

Juan M. Zolezzi, Laboratorio de

Biología Celular y Molecular,

Departamento de Biología, Facultad

de Ciencias, Universidad de

Tarapacá, Gral. Velásquez 1775,

Arica, 1000007, Chile

e-mail: juan.zolezzimoraga@

gmail.com;

Nibaldo C. Inestrosa, Centro de Envejecimiento y Regeneración (CARE), Departamento de Biología Celular y Molecular, Facultad de Ciencias Biológicas, Pontificia Universidad Católica de Chile, Alameda Lib. Bernardo O'Higgins 340, Santiago, 8331150, Chile e-mail:ninestrosa@bio.puc.cl
Alzheimer's disease (AD) is the most common form of age-related dementia. With the expected aging of the human population, the estimated morbidity of AD suggests a critical upcoming health problem. Several lines of research are focused on understanding AD pathophysiology, and although the etiology of the disease remains a matter of intense debate, increased brain levels of amyloid- $\beta(A \beta)$ appear to be a critical event in triggering a wide range of molecular alterations leading to $A D$. It has become evident in recent years that an altered balance between production and clearance is responsible for the accumulation of brain $A \beta$. Moreover, $A \beta$ clearance is a complex event that involves more than neurons and microglia. The status of the blood-brain barrier (BBB) and choroid plexus, along with hepatic functionality, should be considered when $A \beta$ balance is addressed. Furthermore, it has been proposed that exposure to sub-toxic concentrations of metals, such as copper, could both directly affect these secondary structures and act as a seeding or nucleation core that facilitates $A \beta$ aggregation. Recently, we have addressed peroxisomal proliferator-activated receptors (PPARs)-related mechanisms, including the direct modulation of mitochondrial dynamics through the PPAR $\gamma$-coactivator- $1 \alpha$ (PGC- $1 \alpha$ ) axis and the crosstalk with critical aging- and neurodegenerative-related cellular pathways. In the present review, we revise the current knowledge regarding the molecular aspects of $A \beta$ production and clearance and provide a physiological context that gives a more complete view of this issue. Additionally, we consider the different structures involved in $A D$-altered $A \beta$ brain balance, which could be directly or indirectly affected by a nuclear receptor (NR)/PPAR-related mechanism.

Keywords: brain homeostasis, blood-brain barrier, A $\beta$ balance, systemic A $\beta$ clearance, neurodegenerative disorders, nuclear receptors

\section{INTRODUCTION}

During recent decades, it has become evident that the efficiency of an organism's homeostatic mechanisms is closely related to its lifespan, suggesting that aging implies the alteration/modification of several cellular processes necessary to sustain homeostasis (Buga et al., 2011; Popa-Wagner et al., 2011; Basha and Poojary, 2014; Ureshino et al., 2014). Interestingly, aging is recognized as the primary risk factor associated with some chronic degenerative diseases, such as cancer, and/or some neurodegenerative disorders, such as Alzheimer's (AD) or Parkinson's disease (Zlokovic et al., 2010). Moreover, recent published works strongly suggest that the clearance of amyloid- $\beta$ ( $A \beta)$, a key peptide in $\mathrm{AD}$, and the alteration of this mechanism could be closely related to different stages of the disease, e.g., the establishment and/or progression of AD (Figure 1; Cramer et al., 2012).
A genetic component has been described for this disease (familial form); however, it is important to note that genetic-based cases usually account for a limited or reduced number of total cases.

In the present review, we approach the $A \beta$ clearance problem from different perspectives, including the molecular basis of $A \beta$ imbalance, systemic considerations that favor or impair $A \beta$ final excretion, and a wider view of how different tissues should interplay to ensure $A \beta$ balance, thus preventing the development of pathologic processes. In the same manner, based on our experience, we discuss the perspectives regarding nuclear receptors (NRs) stimulation, particularly peroxisome proliferator-activated receptors (PPARs) and some of the cellular signaling pathways that could be behind the effects observed for this family of NRs. 


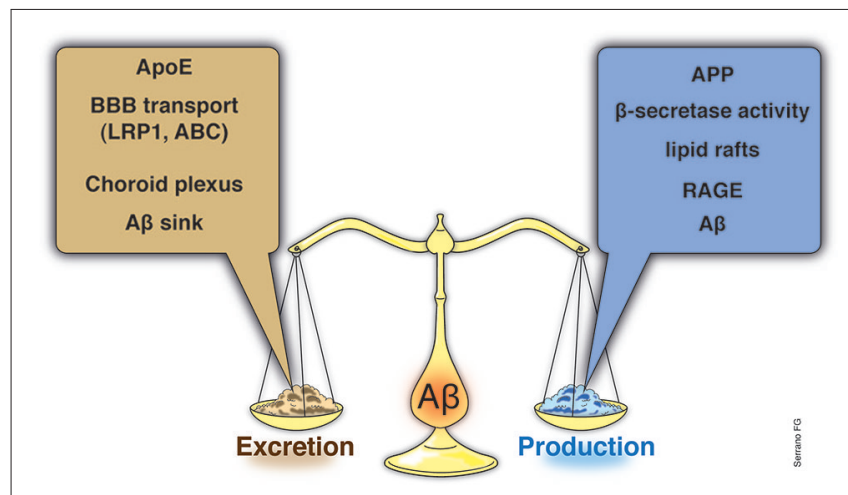

FIGURE 1 | A $\beta$ brain balance, a systemic event. Although the link between $A \beta$ and $A D$ has been known from decades, the importance of $A \beta$ balance, as the result of clearance mechanisms along with brain $A \beta$ production and influx events, has become important only recently. Moreover, the link between the $A \beta$ brain levels and the involvement of brain adjacent tissues, such as the blood-brain barrier (BBB) or the ChP, as well as, with systemic alterations have been emerged as an interesting matter to examine. Indeed, recent studies have explored the potentialities of systemic interventions in order to reduce $A \beta$ brain levels. Several studies have demonstrated that $A p o E$ levels, the main $A \beta$ chaperone within the brain, is a key element of $A \beta$ brain removal and along with the BBB ApoE-related transporters account for almost the total $A \beta$ brain clearance. Additional structures, such as the $\mathrm{ChP}$, has also been demonstrated to play a key role in the A $\beta$ removal from the brain to the CSF and to blood. At the basis of the $A \beta$ brain clearance, emerge an $A \beta$ sink established by the systemic excretion of the $A \beta$, a process carried out mainly by the liver and in less proportion by the kidneys. Whether normal or abnormal levels of $A \beta$ production (increased APP or BACE expression, in the lipid rafts) the A $\beta$ sink in the final $A \beta$ brain balance is clearly critical. If an impaired systemic $A \beta$ excretion due to failure of the liver or kidney, compromise the chances to properly reduce the blood $A \beta$ charge, and additional elements, such as the RAGE, might start to act and inducing $A \beta$ influx to the brain, starting or aggravates the $A \beta$ accumulation. BBB, blood-brain barrier; ChP, Choroid plexus; ApoE, apolipoprotein E; APP, amyloid precursor protein; BACE, $\beta$-site APP cleaving enzyme; RAGE, receptor for advanced glycation end products.

\section{AD OVERVIEW}

$\mathrm{AD}$ is an age-associated neurodegenerative disorder characterized by progressive memory loss and cognitive impairment, and it is related to selective neuronal death in memory and learning brain areas, which eventually leads to patient disability and ultimately death (Braak and Braak, 1991; Morgan et al., 2007; Salmon and Bondi, 2009; Savva et al., 2009; Ballard et al., 2011; SerranoPozo et al., 2011; Godoy et al., 2014). Although many efforts are committed to $\mathrm{AD}$ research, this disease represents a prevalent neurodegenerative disorder that has become a serious public health concern due to the aging of the world population (Lutz et al., 2008). Clinically, AD precipitates a gradual neurodegeneration affecting the short-term memory at the beginning of the disease, followed by long-term memory loss (Braak and Braak, 1991; Gómez-Isla et al., 1997; Perl, 2010). Brain atrophy and gradual loss of neurons, mainly in the hippocampus, frontal cortex, and limbic areas, together with the extracellular accumulation of $A \beta$ plaques and the intra-neuronal formation of neurofibrillary tangles (NFT), are pathological hallmarks of the disease (Salmon and Bondi, 2009; Perl, 2010; Manji et al., 2012). Whether in the familial or sporadic form, increased levels of $\mathrm{A} \beta$ have been described as the starting point of the pathological changes observed in AD (Selkoe, 2001; Karran et al., 2011). A $\beta$ aggregates are often surrounded by dystrophic neurites and reactive glial cells, and $\mathrm{A} \beta$ peptide has been described as the major neurotoxic agent causing these alterations ( $\mathrm{Li}$ et al., 2010). Moreover, recent evidence clearly supports the hypothesis that $A \beta$ oligomers are a key factor in synaptic impairment and the spatial memory decline associated with neuronal dysfunction (Lacor et al., 2004; Haass and Selkoe, 2007; Cerpa et al., 2008; Dinamarca et al., 2012), including the synaptic failure associated with the loss of synaptic proteins that contributes to the progression of the disease (Scheff et al., 2007; Mucke and Selkoe, 2012; Borlikova et al., 2013). Additionally, it have been consistently demonstrated that $A \beta$ also affects energy homeostasis mainly because an altered insulin signaling and due to $\mathrm{A} \beta$-induced mitochondrial dysfunction (Abramov et al., 2004; Paula-Lima et al., 2011; Popa-Wagner et al., 2013), suggesting a severe cellular compromise which leads to general failure of the cellular machinery.

These neurodegenerative pathological changes of $\mathrm{AD}$ ultimately reflect the damage of the neuronal network due to altered synaptic structure and synaptic functionality (Perl, 2010; Sheng et al., 2012; Godoy et al., 2014). Pathologic modifications of the presynaptic neurotransmitter-releasing machinery and/or altered expression of specific postsynaptic proteins, such as the postsynaptic density protein-95 (PSD-95), are at the basis of the synaptic impairment observed in AD (Sheng et al., 2012; Südhof, 2012, 2013). Importantly, although neuronal network damage occurs across the entire brain, the hippocampus, which is associated with memory and cognition, is one of the most critically involved regions (Oliva et al., 2013; Shaerzadeh et al., 2014).

Regrettably, although $\mathrm{AD}$ was described more than a century ago and important progress has been made in the understanding of this disease, effective $\mathrm{AD}$ treatments remain elusive because there are no disease-modifying therapies that can slow or definitively stop the progression of the neurodegenerative process (Langbaum et al., 2013). From the initial cholinergic hypothesis to the actual tau and amyloid hypotheses, research has confirmed several aspects of AD-involved molecular pathways; however, no satisfactory mechanisms have been revealed to enable an effective intervention against this disorder. Recently, an increasing body of evidence has directed attention toward the mechanisms involved with $A \beta$ balance, namely the $A \beta$ production/excretion rate (Cramer et al., 2012; LaFerla, 2012; Fitz et al., 2013; LaClair et al., 2013; Landreth et al., 2013; Price et al., 2013; Tesseur et al., 2013; Veeraraghavalu et al., 2013; Zolezzi and Inestrosa, 2014).

\section{MOLECULAR BASIS OF A $\beta$ BIOLOGY: PHYSIOLOGICAL AND PATHOLOGICAL CONSIDERATIONS}

$\mathrm{A} \beta$ is a 37-49 peptide generated from the post-translational amyloidogenic processing of the amyloid precursor protein (APP), a transmembrane protein that is present in several cell types, including neurons. The precise function of the APP remains not fully understood, although nervous system nerve differentiation during development and both signaling and cell adhesion have been related to this protein (Turner et al., 2003; Priller et al., 2006; Zheng and Koo, 2006). APP possess a highly complex processing 


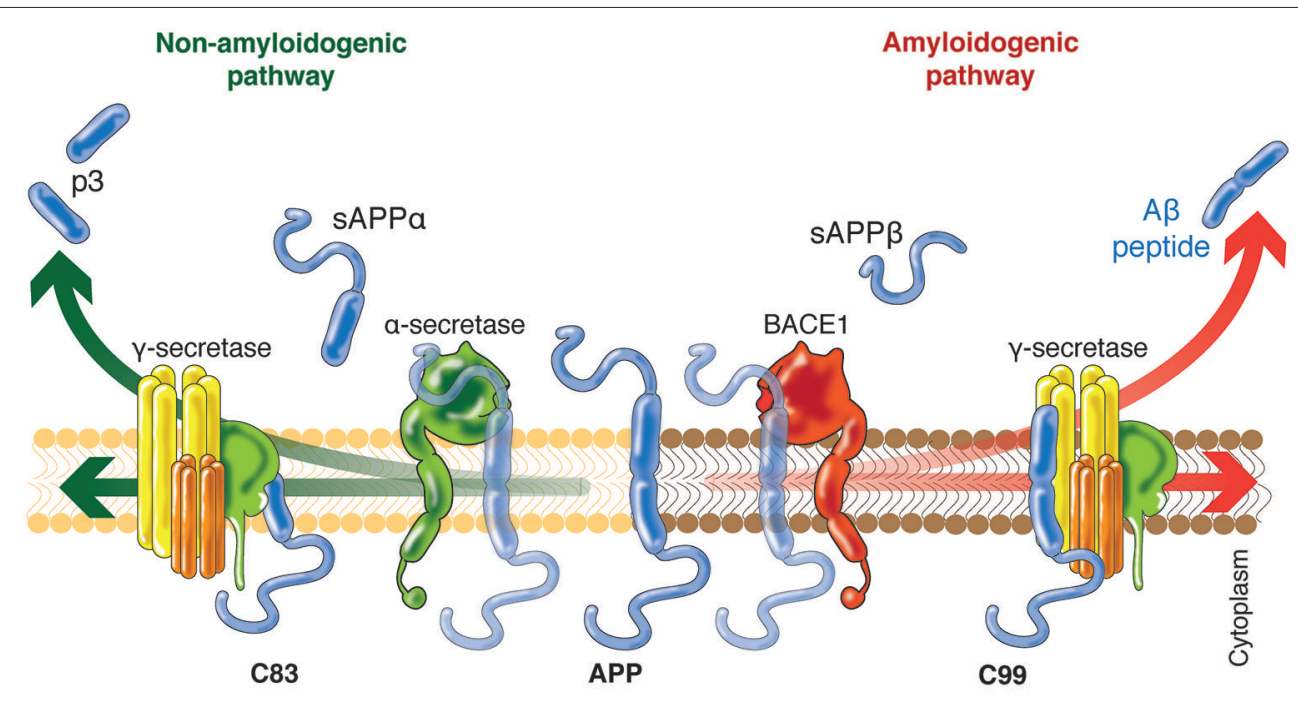

FIGURE 2 | APP processing, critical cellular choice. The main source of $A \beta$ production within the brain are the neurons. Two proteolytic processing pathways of APP have been described with two clear outputs. The non-amyloidogenic pathway will lead to the final release of the $\mathrm{p} 3$ and $\mathrm{SAPP} \alpha$, a small peptide with still poorly understood cell function. The cleaving enzymes which act to produce the SAPP $\alpha$ are the $\alpha$ - and $\gamma$-secretase. On the other hand, the activity of the $\beta$ - and $\gamma$-secretase leads to the formation of the SAPP $\beta$ and the $A \beta$, the main neurotoxic agent described in AD. The role of the $B A C E$ is out of question and it is considered the $A \beta$ production rate limiting enzyme. Interestingly, the recent work of Singh et al. (2013) clearly indicates that external factors might influence the expression levels of BACE, suggesting the potential up-regulation of the amyloidogenic processing of the APP. In the same context, it have been recently proposed that the APP amyloidogenic processing machinery is located in the lipid rafts rich in cholesterol. The increased lipid content within the cells, for example, as a result of increased systemic lipids levels, might also influence which APP processing machinery will be prompted to act. SAPP $\alpha / \beta$, soluble APP fragment $\alpha / \beta$; p3, 3-KDa peptide; BACE, $\beta$-site APP cleaving enzyme. machinery, including three site-specific cleaving enzymes termed $\alpha-, \beta-$, and $\gamma$-secretase, the differential action of which leads to the non-amyloidogenic or amyloidogenic processing of APP (Figure 2). The coordinated processing of $\alpha$ - and $\gamma$-secretase leads to the formation of soluble APP- $\alpha(\operatorname{sAPP} \alpha)$ fragments, while the action of $\beta$ - and $\gamma$-secretase causes the release of sAPP $\beta$ and the neurotoxic A $\beta$ (Grimm et al., 2013; Yan and Vassar, 2014). $\beta$-secretase, also known as $\beta$-site APP cleaving enzyme (BACE1 and 2), is considered to be the $A \beta$ production rate limiting enzyme, and BACE-directed therapy is currently one of the aims of several research projects (Grimm et al., 2013; Buggia-Prévot et al., 2014; Yan and Vassar, 2014). Similarly, mutations in any of the $\gamma$-secretase subunits, particularly presenilin (PSEN1 and 2 ), have been proven to induce the aberrant processing of the $\mathrm{APP}$, causing an increase in $\mathrm{A} \beta$ levels and favoring $\mathrm{AD}$ early onset (Bekris et al., 2011; Benitez et al., 2013; Larner, 2013). Increasing interest in $\beta$ - and $\gamma$-secretase clustering has emerged in various investigations, which indicate that this event is favored in cholesterol-rich domains of the plasma membrane, termed lipid rafts (Kapoor et al., 2010; Marquer et al., 2011). Some authors have proposed that lipid rafts would be appropriate targets of potential therapeutic interventions against AD (Ben Halima and Rajendran, 2011).
The significance of APP processing and the importance of BACE results are evident from several studies focused on understanding the cognitive decline and the memory impairment observed in patients with chromosome 21 trisomy, where APP and BACE genes are encrypted (Mok et al., 2013). The critical role of BACE as an $\mathrm{A} \beta$-level modulator is no longer debated, and recent work has suggested the importance of understanding how BACE polymorphisms determine not only Down's syndrome AD onset but also sporadic AD cases (Zhou et al., 2010; Mok et al., 2013; Natunen et al., 2013). Moreover, the recent work of Singh et al. (2013), which demonstrates that sub-toxic plasma concentrations of copper may influence the expression of BACE1, highlights the importance of non-evident or non-clinical events that could be at the basis of some of the pathological changes that will ultimately lead to AD onset.

It is important to note that the deficient expression of genes related to the non-amyloidogenic processing of APP, such as ADAM 9, 10, and/or 17, which have demonstrated $\alpha$-secretase activity, should also be addressed. These genes are related to increased $A \beta$ levels as a consequence of the increased amyloidogenic processing of APP (Bekris et al., 2011).

Due to the complexity of APP processing and the genes involved in this process (from the APP itself to the genes 
coding for each of the subunits necessary for the APP posttranslational modification), the study of the genetic variations, such as polymorphisms or single nucleotide polymorphisms (SNPs), is mandatory to correctly evaluate each patient and to develop directed therapies that are not based on underestimated genetic conditions. In the same way, we believe that a deep understanding of this matter should enable the development of new in vitro/in vivo models of $\mathrm{AD}$ that are necessary to evaluate new therapeutic strategies.

\section{BRAIN A $\beta$ LEVELS IN THE INTERSTITIAL FLUID (ISF), CEREBROSPINAL FLUID (CSF) AND BLOOD}

Current knowledge indicates that $A \beta$ begins to accumulate outside the cell, within the interstitial fluid (ISF), where its aggregation might be facilitated due to an altered microenvironment leading ultimately to the formation of senile plaques (Näslund et al., 2000; Karran et al., 2011; Li et al., 2012). It was initially believed that plaques were responsible for neuronal damage and the concomitant cognitive impairment, but the poor correlation between plaque burden and cognitive compromise prompted researchers to question the role of the plaque in $\mathrm{AD}$ ethiology (Lesné et al., 2013). Today, it is widely accepted that it is not the plaque but instead the $\mathrm{A} \beta$ oligomers levels that are the basis of neuronal damage (LaFerla et al., 2007; Lesné et al., 2013). Although the following remains controversial, several authors have proposed that the intracellular accumulation of $A \beta$ could account for the initial synapse and neurite damage registered during the first stages of the disease (LaFerla et al., 2007; Gouras et al., 2010; Zheng et al., 2012). The mechanisms regarding intracellular $\mathrm{A} \beta$ accumulation have been proposed to be related to endogenous cellular aspects, such as the intracellular APP export and cleavage, which can occur wherever APP encounters the necessary enzymatic machinery (LaFerla et al., 2007; Gouras et al., 2010; Jiang et al., 2014), and to an altered neuronal catabolism of $\mathrm{A} \beta$ (Nilsson and Saido, 2014). Regarding the first, it is quite important to note that APP have been encountered in different cellular compartments, such as Golgi, endoplasmic reticulum (ER), endosomal, lysosomal, and mitochondrial membranes (Mizuguchi et al., 1992; Xu et al., 1995; Kinoshita et al., 2003; Zheng et al., 2012). On the other hand, autophagy has been recognized as a critical cellular process which impairment results determinant for increased intraneuronal $A \beta$ levels. Alterations in Rab GTPases family members as well as altered activity of lysosomal enzymes, such as cathepsins, are part of the basic cellular mechanism to deal with $\mathrm{A} \beta$ (Nixon et al., 2001; Nilsson and Saido, 2014). As mentioned above, it has been proposed that when this systems fails, it will allow the rise of intracellular $A \beta$ levels leading to the accumulation and aggregation of $\mathrm{A} \beta$ within the cells and, ultimately to cell death (Li et al., 2012; Nilsson and Saido, 2014). Additionally, $A \beta$ reuptake has been described and is of the most interest in the context of the high affinity between $A \beta$ and the $\alpha 7$ nicotinic acetylcholine receptor (LaFerla et al., 2007; Inestrosa et al., 2013), a situation that leads to the internalization of the receptor/A $\beta$ complex and increasing intracellular $A \beta$ levels.

Whether of an extracellular or intracellular origin, the $A \beta$ must finally be removed from brain parenchyma in order to prevent
Table 1 | A $\beta$ levels critical control points.

\begin{tabular}{ll}
\hline Degradation & \\
\hline $\begin{array}{l}\text { Intracellular } \\
\text { Extracellular } \\
\text { monomers } \\
\text { insoluble forms }\end{array}$ & Autophagy (Lysozymes: cathepsins) \\
\hline Transport & Matrix Metalloproteases (MMPs: 1, 2, 9) \\
\hline ApoE & \\
ABC & A $\beta$ chaperone \\
LRP1 & Transporters family related to ApoE movilization \\
SLRP1 & Main ApoE receptor \\
\end{tabular}

ApoE, apolipoprotein E; ABC, ATP binding cassette; LRP1, low density lipoprotein related receptor protein 1; sLRP1, soluble LRP1.

its accumulation and aggregation (Karran et al., 2011). At this point, the activity of glial cells is fundamental not only due to the phagocytic activity that they exert against $A \beta$ (Guo et al., 2004; LaFerla, 2012; Zhu et al., 2012), but because they are the primary source of apolipoprotein E (ApoE), which is the main chaperone of $\mathrm{A} \beta$ within the central nervous system (CNS; LaDu et al., 2000). To date, three isoforms of ApoE have been described $(\varepsilon 2, \varepsilon 3$, and $\varepsilon 4)$, and the ApoE $\varepsilon 4$ variant is considered to be one of the most relevant risk factors for AD (Corder et al., 1993; Zhu et al., 2012; Tai et al., 2014). Additionally, ApoJ, transthyretin and $\alpha 2$-macroglobulin ( $\alpha 2 \mathrm{M}$ ) have been described as secondary chaperones and are considered to play a role in $\mathrm{A} \beta$ brain efflux (Deane et al., 2008). Considering the relevance of ApoE, it is clear that the expression of this chaperone could strongly influence the rate of $A \beta$ brain removal. Several authors have proposed ApoE as a primary target for future $\mathrm{AD}$ therapies (Cramer et al., 2012; Frieden and Garai, 2012; Lane et al., 2012).

Additionally, $\mathrm{A} \beta$ could undergo enzymatic degradation via neprilysin, the main soluble $A \beta$ degrading enzyme, the expression of which has been reported as decreased in brains of several murine models of AD and in in vitro models (Tampellini et al., 2011; Grimm et al., 2013). Moreover, several authors have suggested a direct link between the APP process and neprilysin regulation in a type of feedback regulatory mechanism that is directed by the APP intracellular domain released during APP cleavage (Vásquez et al., 2009; Grimm et al., 2013). However, neprilysin is only able to degrade soluble forms of $A \beta$; thus, once the insoluble $A \beta$ forms, such as fibrils, are present, the role of glial cells and matrix metalloporteases, such as MMP-1, -2 and -9 , is fundamental and, as has been demonstrated systematically, alterations in glial response as well as an altered activity of MMPs could be well related to neurodegeneration and AD (Mroczko et al., 2013; Table 1). In addition to the enzymatic removal of $A \beta$, efflux to the blood across the blood-brain barrier (BBB) and via drainage from the CSF complements the brain $A \beta$ clearance system (Deane et al., 2008).

\section{BBB AND CHOROID PLEXUS (ChP) A $\beta$ TRANSPORTERS}

$A \beta$ transport across the $\mathrm{BBB}$ is the main pathway in maintaining appropriate brain $A \beta$ levels. While this primary mechanism directly exports $A \beta$ from the brain ISF to the blood, a 
secondary pathway involving ChP/CSF bulk flow and CSF/blood $\mathrm{A} \beta$ exchange at the Virchow-Robin space also contributes to brain $\mathrm{A} \beta$ balance (Deane et al., 2008). Due to its electrochemical nature, $\mathrm{A} \beta$ requires specialized carriers to cross the $\mathrm{BBB}$ and $\mathrm{ChP}$ barriers (Zlokovic, 2010; Zolezzi and Inestrosa, 2013). Importantly, the carriers present at each barrier are the same (Pascale et al., 2011).

The low-density lipoprotein receptor-related protein (LRP1 and 2) and the ATP binding cassette (ABCB1, C1, G2, and G4) are the two main families of transporters related to brain $A \beta$ efflux (Bell et al., 2007; Bell and Zlokovic, 2009; Jaeger et al., 2009; Cramer et al., 2012; Kanekiyo et al., 2012). Although both pathways play an important role in $A \beta$ clearance, several studies suggest that $\mathrm{BBB}$ alteration is not only a consequence of the $\mathrm{AD}$ neurodegenerative process but could be the basis of these changes (Zlokovic, 2010, 2011; Erickson and Banks, 2013; Zolezzi and Inestrosa, 2013). In the same manner, any genetic variation of such transporters could have an enormous impact on the establishment and progression of AD (Erickson and Banks, 2013; Zolezzi and Inestrosa, 2013).

It is important to note that the main $A \beta$ chaperone in the plasma is the soluble form of the LRP and in the CSF is the lipocalin-type prostaglandin $\mathrm{D}$ synthase $\beta$-trace (Deane et al., 2008; Sagare et al., 2011). This situation is most relevant for final $\mathrm{A} \beta$ elimination, a process that primarily occurs in the liver (Ghiso et al., 2004; Tamaki et al., 2006; Sagare et al., 2012), and to a lesser extent, in the kidneys (Ghersi-Egea et al., 1996; Sagare et al., 2007; Figure 3).

\section{AD AND THE SYSTEMIC REGULATION OF A $\beta$ LEVELS: THE ROLE OF THE LIVER AND KIDNEYS}

As previously mentioned, the liver is the most important place for final A $\beta$ removal, where the binding of liver LRP1 to the $\mathrm{A} \beta$ and the posterior elimination generates a sink that ensures continuous $A \beta$ elimination (Sagare et al., 2012). The works of Tamaki et al. (2007) and Ito et al. (2010) provided evidence that the blockade of LRP1-A $\beta$ binding in the liver causes an increase of plasmatic $A \beta$ levels, which could be related with increases in brain $A \beta$ levels. It has been demonstrated that an increase in the plasma levels of $A \beta$ could induce $A \beta$ influx into the brain through a specific $\mathrm{BBB}$ transporter, the receptor for advanced glycation end products (RAGE; Deane et al., 2012; Sagare et al., 2012), leading to accumulation and aggregation in the brain, with subsequent damage to the neuronal network. Therefore, the appropriate expression level of liver LRP and the health status of hepatocytes are of great relevance in regulating systemic $A \beta$ levels and in avoiding dangerous increases of this neurotoxic agent (Sagare et al., 2012).

On the other hand, although the renal excretion of sLRP and $A \beta$ has been described, the relevance of this process has been poorly addressed (Sagare et al., 2007; Shea et al., 2014). However, as evidenced by several authors, vascular health, as a result of an appropriate renal function, plays a fundamental role in $\mathrm{AD}$ establishment and progression (Zlokovic, 2010, 2011; Erickson and Banks, 2013; Zolezzi and Inestrosa, 2013, 2014). Cerebral microinfarcts, microbleedings, elevated blood

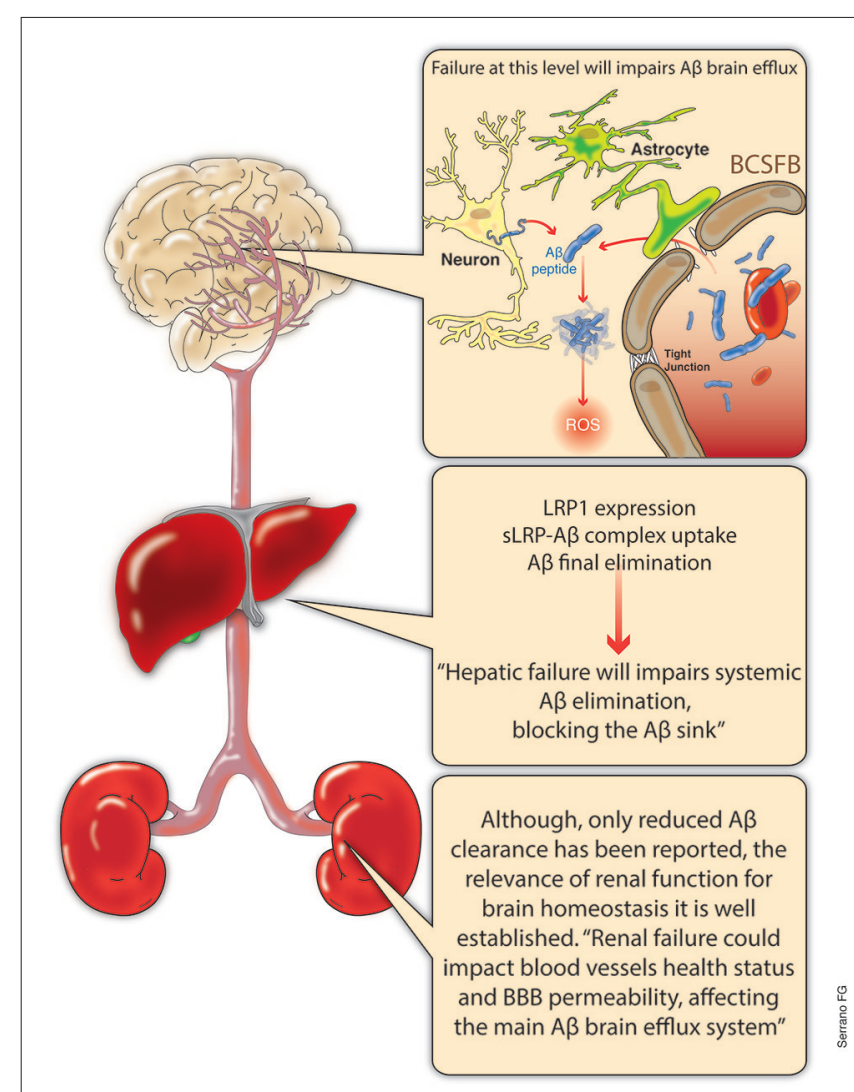

FIGURE 3 | A $\boldsymbol{\beta}$ balance, systemic overview. The main discussion regarding $A \beta$ clearance has been centered at the brain level. Increased production and decreased removal from the brain certainly constitutes a highly relevant issue. The relevance of the BBB integrity or the $A \beta$ excretion through the $\mathrm{ChP}$ are now recognized as key elements regarding $\mathrm{A} \beta$ brain levels. However, a growing body of evidence suggest the critical role of systemic final excretion of $A \beta$ in $A D$. In this regard, expression levels of LRP 1 within the liver and hepatocyte are critical for the appropriate liver excretion of $A \beta$, which could account for up to the $60 \%$ of the total systemic $A \beta$ clearance. On the other hand, even when not fully understood, kidneys not only play an important role in systemic $A \beta$ clearance, but the precise renal function might account for blood vessels health and appropriate blood pressure levels which could influence the BBB integrity and its functionality. LRP, low density lipoprotein-related receptor protein; sLRP-A $\beta$, soluble LRP bond to $A \beta$; BCSFB, brain-cerebrospinal fluid barrier; ChP, choroid plexus.

pressure, cardiac failure, and stroke are only some of the pathological conditions that reflect or could alter blood vessels (Zlokovic, 2010, 2011). Moreover, the relationship between the compromise of renal function and pathological changes in the brain has been demonstrated (Liu et al., 2008; Busch et al., 2012). However, there is a lack of knowledge regarding this issue, and it should be considered when a multisystemic approach to $\mathrm{AD}$ or other neurodegenerative disorders is pursued.

\section{NUCLEAR RECEPTORS (NRs): PPARs AND THEIR POTENTIAL ROLE IN A MULTISYSTEMIC THERAPEUTIC STRATEGY}

NRs are a highly complex transcription factor superfamily that is fundamental for several cell processes. The main function of NRs has been related to both the extracellular and intracellular 
media (Olefsky, 2001). NRs play a critical role within cells, as indicated in several reports that correlated NR dysfunction with pathological conditions such as cancer, insulin resistance and infertility (Olefsky, 2001; Gronemeyer et al., 2004). As cell sensors, NRs interact with different cellular signaling pathways, such as Wnt, phosphoinositide 3-kinase (PI3K) and mitogen-activated protein kinases (MAPK), exerting gene expression regulation of a wide range of target genes (Mulholland et al., 2005; Fuenzalida et al., 2007; Inestrosa and Toledo, 2008).

NRs can be divided into two main categories: Type I, such as the androgen, estrogen, and progesterone receptors; and Type II, including the thyroid receptor, the retinoid $\mathrm{X}$ receptor (RXR) (homodimer), the vitamin $\mathrm{D}$ receptor, the retinoic acid receptor, the liver X receptor (LXR), and the PPARs (Olefsky, 2001; Mulholland et al., 2005; Zolezzi and Inestrosa, 2013, 2014). The main difference between types is their ability to form homodimers (Type I) or heterodimers with the RXR (Type II) (Mulholland et al., 2005).

Several studies have been conducted on the pharmacological potentialities of different NRs, including cancer research, neurodegenerative disorders, and acute brain injury, among others (Aleshin et al., 2013; Fu et al., 2014; Garattini et al., 2014). Among the NR superfamily, PPARs are the most studied ones (Aleshin et al., 2013).

To date, three different mammalian PPARs have been identified: PPAR $\alpha, \operatorname{PPAR} \beta / \delta$, and PPAR $\gamma$ (Neher et al., 2012). Although all PPARs have been described in both the adult and developing brain (Heneka and Landreth, 2007), PPAR $\gamma$ is the most studied isoform and has shown the most promising neuroprotective effects in different models of neurodegenerative disorders, such as AD (Inestrosa et al., 2005, 2013; Santos et al., 2005; Toledo and Inestrosa, 2010; Chen et al., 2012; Neher et al., 2012). A common feature of PPARs is that part of it activity is mediated by the direct binding to DNA, specifically to the peroxisome proliferators-response elements (PPREs), a DNA consensus sequence (AGGTCA-N-AGGTCA) localized mainly at the promoter region of PPARs-genes (Heinäniemi et al., 2007). However, as mentioned above, when potential PPARs target genes are evaluated, the RXR target genes must also be considered. Several genes have been linked to the different PPARs, including some Apo-family of lipid transporters; other nuclear receptors, such as LXR; the UCP-3 (energy metabolism); among others (Kanehisa and Goto, 2000; Heinäniemi et al., 2007; Kanehisa et al., 2014). Interestingly, some authors have demonstrated that among the PPAR target genes might also be present some key components of relevant cellular signaling pathways, such as Wnt (Toledo and Inestrosa, 2010) and mTOR (Hagland et al., 2013), among others.

Although PPARs were identified long ago, the recent work of Cramer et al. (2012) has directed attention to this nuclear receptor subgroup as a key target for $\mathrm{A} \beta$ clearance in $\mathrm{AD}$ therapy. Indeed, prior to Cramer's work, several authors have already stated the relevant role of PPARs in the brain $A \beta$-clearance (Camacho et al., 2004; Kalinin et al., 2009; Escribano et al., 2010; Espuny-Camacho et al., 2010). Our laboratory and others, have been working with PPARs for many years, and we have systematically described the benefits of PPARs activation in several in vitro and in vivo models of AD (Fuentealba et al., 2004;
Inestrosa et al., 2005, 2012; Fuenzalida et al., 2007; Nenov et al., 2014). Moreover, recent works suggest an interesting role for PPARs in mitochondrial dysfunction protection and functionality (Zolezzi et al., 2013a,b), which could be part of a series of PPARtriggered mechanisms at the foundation of the benefits observed against $\mathrm{AD}$.

However, it is important to note, that the vast majority of information regarding PPARs benefits against neurodegenerative disorders, such as $\mathrm{AD}$, have arose from in vitro and in vivo studies based on different animal models. Moreover, some clinical trials have been conducted, with dissimilar results, and others are actually under development (Ryan, 2014). On this regard, several questions remains regarding PPARs mechanisms of action.

\section{PPARs AND THE BBB}

Among the $A \beta$ neurotoxic mechanisms, oxidative stress and mitochondrial damage are two of the most cited effects of $A \beta$ exposure. Several authors have suggested that the perivascular accumulation of $\mathrm{A} \beta$ damages the $\mathrm{BBB}$, leading to microbleedings, inflammatory reactions, and subsequent damage to the neuronal network (Zlokovic, 2010; Popa-Wagner et al., 2013; Zolezzi and Inestrosa, 2013). On this regard, several authors have demonstrated the role of PPARs as an endothelial protective agents (Zhou et al., 2008; Bae et al., 2010; Kröller-Schön et al., 2013; Zarzuelo et al., 2013; d'Uscio et al., 2014; Hawkes et al., 2014). Recently, it has been demonstrated that PPARs are able to protect endothelial cells from oxidative damage, thus preventing vascular dysfunction, which could favor brain parenchyma alterations (d'Uscio et al., 2012; Papadopoulos et al., 2013). Based on current knowledge and on our own work, we have proposed that PPAR activation, through natural or synthetic ligands, could protect and recover BBB integrity and functionality by increasing cell antioxidant capacity and improving energy metabolism, leading to the increased expression of specific transporters that could influence the $A \beta$-clearance rate (Nicolakakis et al., 2008; Zolezzi and Inestrosa, 2013; Zolezzi et al., 2013b; Hawkes et al., 2014). Energy metabolism is vital for both, neurons and the BBB, primarily because the preservation of the ion gradients (in the case of neurons) and the traffic across the $\mathrm{BBB}$ requires large amounts of energy (Abbott et al., 2010; Liebner and Plate, 2010; Popa-Wagner et al., 2013).

Although the main effects resulting from PPAR stimulation have been related to microglial and astrocytic activation as the key events that allow brain $\mathrm{A} \beta$ clearance (Mandrekar-Colucci et al., 2012; Yamanaka et al., 2012), additional mechanisms, such as the PPAR $\gamma$-LXR-mediated increased expression of ApoE (Cramer et al., 2012; Mandrekar-Colucci et al., 2012) along with the increased expression of ApoE-A $\beta$ carriers (the ABC family of transporters), indicate a close relationship between these mechanisms and the foundational role of $\mathrm{A} \beta$ trafficking across the $\mathrm{BBB}$ that can properly explain the benefits observed after PPAR stimulation in several models of AD (Mysiorek et al., 2009; Cramer et al., 2012; Hoque et al., 2012; Figure 4). Importantly, although different authors recognize the relevance of the BBB traffic system, only a small proportion of research has focused on the diseaserelated expression variations of BBB transporters. Less is known 


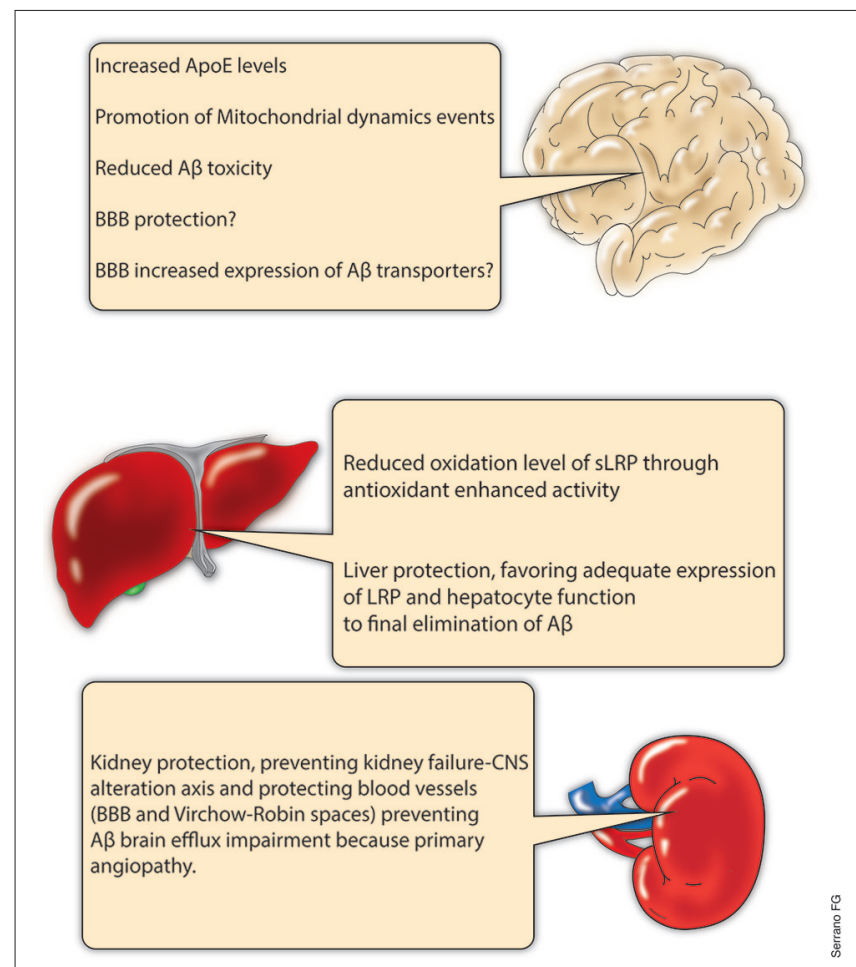

FIGURE 4 | PPARs, potential for systemic A $\beta$ clearance. PPARs are a complex subfamily of NRs. Several PPARs agonists have been studied under different physiological and pathological conditions, and numerous effects have been reported for this group of drugs in several organs. Central nervous system (CNS), liver and kidneys are some of the tissues which have demonstrated to respond to PPAR agonist treatments. In this regard, the present scheme summarizes part of the current knowledge relative to PPARs agonists and the potential that they might exert in different organs regarding the $A \beta$ systemic clearance. Of course, much research is needed in order to properly address the importance of PPARs as therapeutic agents, but the approach presented here suggest the study of new therapeutic strategies including additional intervention levels.

regarding the disease-induced modification of transporters at the $\mathrm{ChP}$, indicating that this is an enormous field to investigate.

\section{PPARS AND THE SYSTEMIC CLEARANCE OF A $\beta$}

As previously indicated, the main plasmatic chaperone protein of $A \beta$ is sLRP (Tamaki et al., 2006; Sagare et al., 2012). Interestingly, sLRP has been reported to be in an oxidized state (which reduces the affinity of sLRP for A $\beta$ ) in AD patients (Sagare et al., 2007). Several investigations suggest that the activation of PPARs can protect against oxidative damage (Hernanz et al., 2012). Additionally, PPARs have been demonstrated to protect the liver, thus preventing the impairment of systemic antioxidant production and the loss of intact hepatocytes with LRP surface expression, which enables the final excretion of $\mathrm{A} \beta$ (Iwaisako et al., 2012; Patterson et al., 2012; Figure 4).

Similarly, several authors have reported the protective activity of PPARs at the renal level. Renal fibrosis or necrosis after ischemic insults are two of the events that could influence renal functionality, thereby altering the clearance rate of $A \beta$ in the kidneys (Fedorova et al., 2013; Li et al., 2013). Regrettably, there is little information regarding PPARs and kidneys and PPAR implication in $\mathrm{AD}$ or in other neurodegenerative disorders. However, it is possible that even when the $A \beta$ clearance rate is not a determinant for a systemic $A \beta$ balance, the role that kidneys play in blood pressure and/or the filtration of excretion products should have a great impact not only at the blood vessel level but also in the brain (Figure 4).

\section{MOLECULAR BASIS OF PPARS ACTIVITY}

The complexity of the response to PPAR stimulation arises from several cellular signaling pathways that have been described to be related to it. Interactions with several antioxidant and anti-inflammatory regulatory pathways, such as nuclear factor kappa-light-chain-enhancer of activated B cells (NF- $\mathrm{kB})$, nuclear factor erythroid 2-related factor (NRF2), brain-derived neurotrophic factor $(\mathrm{BDNF})$, and the $\mathrm{Wnt} / \beta$-catenin pathway have been described (Zhang et al., 2011; Benito et al., 2012; Martín et al., 2012; Haskew-Layton et al., 2013; Benedetti et al., 2014). Additionally, it has been proposed that $\operatorname{PPAR} \gamma$ can upregulate Bcl-2, which is an antiapoptotic protein and a Wnt target gene (Fuentealba et al., 2004; Fuenzalida et al., 2007). Over the last few years, it has been further proposed that the administration of PPAR agonists induces additional effects regarding neuronal functionality, including neurite outgrowth, and has a direct effect on mitochondrial fusion-fission dynamics (Feinstein et al., 2005; Chiang et al., 2012; Cho et al., 2013; Quintanilla et al., 2013; Zolezzi and Inestrosa, 2013; Zolezzi et al., 2013a).

Recently, we found that PPAR agonists are also able to induce mitochondrial dynamic events through PGC- $1 \alpha$. This process will prevent the mitochondrial dysfunction caused by oxidative insults, suggesting that cell metabolism is protected and that mitochondrial biogenesis should increase (Feinstein et al., 2005; Chiang et al., 2012; Pipatpiboon et al., 2012; Popa-Wagner et al., 2013; Zolezzi and Inestrosa, 2013; Zolezzi et al., 2013a). This latter finding is highly relevant considering that mitochondrial dynamics have recently been described as a critical mechanism associated with mitochondrial and cellular fate after critical insults (Manji et al., 2012). Such dynamics help sustain cell metabolism, and successive fusion-fission cycles enable the elimination of dysfunctional organelles and the repair of mitochondrial DNA that could be damaged after a toxic challenge (Haemmerle et al., 2011; Hondares et al., 2011; Silva et al., 2013; Zolezzi et al., 2013a). Moreover, as noted for antioxidant activity, the mitochondrial effects derived from PPAR activation could also be related to several cell signaling pathways such as Wnt (Silva-Alvarez et al., 2013). Recently, the activity of PPARs has also been proposed to be related to sirtuins (SIRT; Wang et al., 2013; Yang et al., 2013; Godoy et al., 2014), thus opening a new area for research and increasing the complexity of the molecular mechanisms involved with cellular PPAR response.

\section{FINAL CONSIDERATIONS}

Although published several years ago, the work of Cramer et al. (2012) clearly positioned $A \beta$ clearance-related mechanisms as very promising candidates for future $\mathrm{AD}$ therapies. Moreover, their work prompted several authors to replicate or test old and new NR agonists to assess their effectiveness against $A \beta$ 
accumulation. However, integrated studies that include systemic $\mathrm{A} \beta$ clearance and the effectiveness of systemic $\mathrm{AD}$ therapies are scarce. Our recommendation is that $\mathrm{AD}$ should be approached not only as a CNS issue but also from a multi-systemic perspective to accurately establish and define directed therapeutic interventions.

Indeed, the effects described by Cramer et al. (2012) and others partly involve the PPARs and suggest that PPARs should be considered as putative AD drugs. However, several questions have emerged regarding Cramer's work which have highlighted the poor correlation of the benefits observed from bexarotene administration and the pathological markers evaluated by these researchers. Considering our experience on the subject, we believe that part of the controversy generated by Cramer's work is due to a poor consideration of the mechanism behind PPAR stimulation. Thus, we propose a wider view of the $A \beta$ clearance problem and the main key elements related to efficient $A \beta$ elimination. Moreover, it is possible that different intervention points at which PPARs could influence the health of the systemic $A \beta$ clearance machinery might be defined in the near future. As pointed previously, several clinical trials have attempted to transfer the in vivo results to real patients without success, but we think that there are still too many questions regarding NRs function (and particularly PPARs) to accurately estimate the effects of NR and PPAR stimulation.

\section{AUTHOR CONTRIBUTIONS}

Each author participated actively in different manuscript preparation stages. Juan M. Zolezzi, Nibaldo C. Inestrosa, Sussy BastíasCandia and Manuel J. Santos discussed and designed the present work. Juan M. Zolezzi and Nibaldo C. Inestrosa wrote and checked each subsection as well as the final version of the manuscript. Sussy Bastías-Candia and Manuel J. Santos wrote and corrected different subsection of the manuscript, as well as critically evaluated the final version of this work. Approval of the submitted final version was done by Nibaldo C. Inestrosa and Juan M. Zolezzi.

\section{ACKNOWLEDGMENTS}

This work was supported by grants PFB 12/2007 from the Basal Centre for Excellence in Science and Technology, FONDECYT 1120156, to Nibaldo C. Inestrosa; and FONDECYT 11130033 to Juan M. Zolezzi.

\section{REFERENCES}

Abbott, N. J., Patabendige, A. A. K., Dolman, D. E. M., Yusof, S. R., and Begley, D. J. (2010). Structure and function of the blood-brain barrier. Neurobiol. Dis. 37, 13-25. doi: 10.1016/j.nbd.2009.07.030

Abramov, A. Y., Canevari, L., and Duchen, M. R. (2004). $\beta$-amyloid peptides induce mitochondrial dysfunction and oxidative stress in astrocytes and death of neurons through activation of NADPH oxidase. J. Neurosci. 24, 565-575. doi: 10. 1523/jneurosci.4042-03.2004

Aleshin, S., Strokin, M., Sergeeva, M., and Reiser, G. (2013). Peroxisome proliferator activated receptor (PPAR) $\beta / \delta$, a possible nexus of PPAR $\alpha$ - and PPAR $\gamma$ dependent molecular pathways in neurodegenerative diseases: review and novel hypotheses. Neurochem. Int. 63, 322-330. doi: 10.1016/j.neuint.2013.06.012

Bae, E. H., Kim, I. J., Ma, S. K., and Kim, S. W. (2010). Rosiglitazone prevents the progression of renal injury in DOCA-salt hypertensive rats. Hypertens. Res. 33, 255-262. doi: 10.1038/hr.2009.217
Ballard, C., Gauthier, S., Corbett, A., Brayne, C., Aarsland, D., and Jones, E. (2011). Alzheimer's disease. Lancet 377, 1019-1031. doi: 10.1016/S01406736(10)61349-9

Basha, P. M., and Poojary, A. (2014). Mitochondrial dysfunction in aging rat brain regions upon chlorpyrifos toxicity and cold stress: an interactive study. Cell. Mol. Neurobiol. 34, 737-756. doi: 10.1007/s10571-014-0056-7

Bekris, L. M., Galloway, N. M., Millard, S., Lockhart, D., Li, G., Galasko, D. R., et al. (2011). Amyloid precursor protein (APP) processing genes and cerebrospinal fluid APP cleavage product levels in Alzheimer's disease. Neurobiol. Aging 32, 556.e13-556.e23. doi: 10.1016/j.neurobiolaging.2010.10.020

Bell, R. D., Sagare, A. P., Friedman, A. E., Bedi, G. S., Holtzman, D. M., Deane, R., et al. (2007). Transport pathways for clearance of human Alzheimer's amyloid $\beta$-peptide and apolipoprotein $\mathrm{E}$ and $\mathrm{J}$ in the mouse central nervous system. $J$. Cereb. Blood Flow Metab. 27, 909-918. doi: 10.1038/sj.jcbfm.9600419

Bell, R. D., and Zlokovic, B. V. (2009). Neurovascular mechanisms and blood-brain barrier disorder in Alzheimer's disease. Acta Neuropathol. 11, 103-113. doi: 10. 1007/s00401-009-0522-3

Ben Halima, S., and Rajendran, L. (2011). Membrane anchored and lipid raft targeted $\beta$-secretase inhibitors for Alzheimer's disease therapy. J. Alzheimers Dis. 24(Suppl. 2), 143-152. doi: 10.3233/JAD-2011-110269

Benedetti, E., D’Angelo, B., Cristiano, L., Di Giacomo, E., Fanelli, F., Moreno, S., et al. (2014). Involvement of peroxisome proliferator-activated receptor $\beta / \delta$ $(\mathrm{PPAR} \beta / \delta)$ in BDNF signaling during aging and in Alzheimer disease: possible role of 4-hydroxynonenal (4-HNE). Cell Cycle 13, 1335-1344. doi: 10.4161/cc. 28295

Benitez, B. A., Karch, C. M., Cai, Y., Jin, S. C., Cooper, B., Carrell, D., et al. (2013). The PSEN1, p.E318G variant increases the risk of Alzheimer's disease in APOE$\epsilon 4$ carriers. PLoS Genet. 9:e1003685. doi: 10.1371/journal.pgen.1003685

Benito, C., Tolon, R. M., Castillo, A. I., Ruiz-Valdepenas, L., Martinez-Orgado, J. A., Fernandez-Sanchez, F. J., et al. (2012). $\beta$-Amyloid exacerbates inflammation in astrocytes lacking fatty acid amide hydrolase through a mechanism involving PPAR-alpha, PPAR-gamma and TRPV1, but not $\mathrm{CB}(1)$ or $\mathrm{CB}(2)$ receptors. $\mathrm{Br}$. J. Pharmacol. 166, 1474-1489. doi: 10.1111/j.1476-5381.2012.01889.x

Borlikova, G. G., Trejo, M., Mably, A. J., Mc Donald, J. M., Sala Frigerio, C., Regan, C. M., et al. (2013). Alzheimer brain-derived amyloid $\beta$-protein impairs synaptic remodeling and memory consolidation. Neurobiol. Aging 34, 1315-1327. doi: 10. 1016/j.neurobiolaging.2012.10.028

Braak, H., and Braak, E. (1991). Neuropathological stageing of Alzheimer-related changes. Acta Neuropathol. 82, 239-259. doi: 10.1007/bf00308809

Buga, A. M., Vintilescu, R., Pop, O. T., and Popa-Wagner, A. (2011). Brain aging and regeneration after injuries: an organismal approach. Aging Dis. 2, 64-79.

Buggia-Prévot, V., Fernandez, C. G., Riordan, S., Vetrivel, K. S., Roseman, J., Waters, J., et al. (2014). Axonal BACE1 dynamics and targeting in hippocampal neurons: a role for Rab11 GTPase. Mol. Neurodegener. 9:1. doi: 10.1186/1750-1326-9-1

Busch, S., Wu, L., Feng, Y., Gretz, N., Hoffmann, S., and Hammes, H. P. (2012). Alzheimer's disease and retinal neurodegeneration share a consistent stress response of the neurovascular unit. Cell. Physiol. Biochem. 30, 1436-1443. doi: $10.1159 / 000343331$

Camacho, I. E., Serneels, L., Spittaels, K., Merchiers, P., Dominguez, D., and De Strooper, B. (2004). Peroxisome-proliferator-activated receptor gamma induces a clearance mechanism for the amyloid-beta peptide. J. Neurosci. 24, 1090810917. doi: 10.1523/jneurosci.3987-04.2004

Cerpa, W., Dinamarca, M. C., and Inestrosa, N. C. (2008). Structure-function implications in Alzheimer's disease: effect of Abeta oligomers at central synapses. Curr. Alzheimer Res. 5, 233-243. doi: 10.2174/156720508784533321

Chen, Y. C., Wu, J. S., Tsai, H. D., Huang, C. Y., Chen, J. J., Sun, G. Y., et al. (2012). Peroxisome proliferator-activated receptor gamma (PPAR- $\gamma$ ) and neurodegenerative disorders. Mol. Neurobiol. 46, 114-124. doi: 10.1007/s12035-012-8259-8

Chiang, M. C., Chern, Y., and Huang, R. N. (2012). PPARgamma rescue of the mitochondrial dysfunction in Huntington's disease. Neurobiol. Dis. 45, 322-328. doi: 10.1016/j.nbd.2011.08.016

Cho, D. H., Lee, E. J., Kwon, K. J., Shin, C. Y., Song, K. H., Park, J. H., et al. (2013). Troglitazone, a thiazolidinedione, decreases tau phosphorylation through the inhibition of cyclin-dependent kinase 5 activity in SH-SY5Y neuroblastoma cells and primary neurons. J. Neurochem. 126, 685-695. doi: 10.1111/jnc.12264

Corder, E. H., Saunders, A. M., Strittmatter, W. J., Schmechel, D. E., Gaskell, P. C., Small, G. W., et al. (1993). Gene dose of apolipoprotein E type 4 allele and the risk of Alzheimer's disease in late onset families. Science 261, 921-923. doi: 10. $1126 /$ science. 8346443 
Cramer, P. E., Cirrito, J. R., Wesson, D. W., Lee, C. Y., Karlo, J. C., Zinn, A. E., et al. (2012). ApoE-directed therapeutics rapidly clear $\beta$-amyloid and reverse deficits in AD mouse models. Science 335, 1503-1506. doi: 10.1126/science.1217697

Deane, R., Sagare, A., and Zlokovic, B. (2008). The role of the cell surface LRP and soluble LRP in blood-brain barrier A $\beta$ clearance in Alzheimer's disease. Curr. Pharm. Des. 14, 1601-1605. doi: 10.2174/138161208784705487

Deane, R., Singh, I., Sagare, A. P., Bell, R. D., Ross, N. T., LaRue, B., et al. (2012). A multimodal RAGE-specific inhibitor reduces amyloid $\beta$-mediated brain disorder in a mouse model of Alzheimer's disease. J. Clin. Invest. 122, 1377-1392. doi: 10.1172/JCI58642

Dinamarca, M. C., Ríos, J. A., and Inestrosa, N. C. (2012). Postsynaptic receptors for amyloid- $\beta$ oligomers as mediators of neuronal damage in Alzheimer's Disease. Front. Physiol. 3:464. doi: 10.3389/fphys.2012.00464

d'Uscio, L. V., Das, P., Santhanam, A. V., He, T., Younkin, S. G., and Katusic, Z. S. (2012). Activation of PPAR $\delta$ prevents endothelial dysfunction induced by overexpression of amyloid- $\beta$ precursor protein. Cardiovasc. Res. 96, 504-512. doi: $10.1093 / \mathrm{cvr} / \mathrm{cvs} 266$

d’Uscio, L. V., He, T., Santhanam, A. V., Tai, L. J., Evans, R. M., and Katusic, Z. S. (2014). Mechanisms of vascular dysfunction in mice with endothelium-specific deletion of the PPAR- $\delta$ gene. Am. J. Physiol. Heart Circ. Physiol. 306, H1001H1010. doi: 10.1152/ajpheart.00761.2013

Erickson, M. A., and Banks, W. A. (2013). Blood-brain barrier dysfunction as a cause and consequence of Alzheimer's disease. J. Cereb. Blood Flow Metab. 33, 1500-1513. doi: 10.1038/jcbfm.2013.135

Escribano, L., Simón, A. M., Gimeno, E., Cuadrado-Tejedor, M., López de Maturana, R., García-Osta, A., et al. (2010). Rosiglitazone rescues memory impairment in Alzheimer's transgenic mice: mechanisms involving a reduced amyloid and tau pathology. Neuropsychopharmacology 35, 1593-1604. doi: 10. 1038/npp. 2010.32

Espuny-Camacho, I., Dominguez, D., Merchiers, P., Van Rompaey, L., Selkoe, D., and De Strooper, B. (2010). Peroxisome proliferator-activated receptor gamma enhances the activity of an insulin degrading enzyme-like metalloprotease for amyloid-beta clearance. J. Alzheimers Dis. 20, 1119-1132. doi: 10.3233/JAD2010-091633

Fedorova, L. V., Sodhi, K., Gatto-Weis, C., Puri, N., Hinds, T. D. Jr., Shapiro, J. L., et al. (2013). Peroxisome proliferator-activated receptor $\delta$ agonist, HPP593, prevents renal necrosis under chronic ischemia. PLoS One 8:e64436. doi: 10. 1371/journal.pone.0064436

Feinstein, D. L., Spagnolo, A., Akar, C., Weinberg, G., Murphy, P., Gavrilyuk, V., et al. (2005). Receptor-independent actions of PPAR thiazolidinedione agonists: is mitochondrial function the key? Biochem. Pharmacol. 70, 177-188. doi: 10. 1016/j.bcp.2005.03.033

Fitz, N. F., Cronican, A. A., Lefterov, I., and Koldamova, R. (2013). Comment on "ApoE-directed therapeutics rapidly clear $\beta$-amyloid and reverse deficits in AD mouse models". Science 340:924. doi: 10.1126/science.1235809

Frieden, C., and Garai, K. (2012). Structural differences between apoE3 and apoE4 may be usedful in developing therapeutic agents for Alzheimer's disease. Proc. Natl. Acad. Sci. U S A 109, 8913-8918. doi: 10.1073/pnas.12070 22109

Fu, W., Yao, J., Huang, Y., Li, Q., Li, W., Chen, Z., et al. (2014). LXR agonist regulates the carcinogenesis of PCa via the SOCS3 pathway. Cell. Physiol. Biochem. 33, 195-204. doi: 10.1159/000356662

Fuentealba, R. A., Farias, G., Scheu, J., Bronfman, M., Marzolo, M. P., and Inestrosa, N. C. (2004). Signal transduction during amyloid- $\beta$-peptide neurotoxicity: role in Alzheimer disease. Brain Res. Brain Res. Rev. 47, 275-289. doi: 10.1016/j. brainresrev.2004.07.018

Fuenzalida, K., Quintanilla, R., Ramos, P., Piderit, D., Fuentealba, R. A., Martinez, G., et al. (2007). Peroxisome proliferator-activated receptor $\gamma$ up-regulates the $\mathrm{Bcl}-2$ anti-apoptotic protein in neurons and induces mitochondrial stabilization and protection against oxidative stress and apoptosis. J. Biol. Chem. 282, 3700637015. doi: 10.1074/jbc.M700447200

Garattini, E., Bolis, M., Garattini, S. K., Fratelli, M., Centritto, F., Paroni, G., et al. (2014). Retinoids and breast cancer: from basic studies to the clinic and back again. Cancer Treat. Rev. 40, 739-749. doi: 10.1016/j.ctrv.2014.01.001

Ghersi-Egea, J. F., Gorevic, P. D., Ghiso, J., Frangione, B., Patlak, C. S., and Fenstermacher, J. D. (1996). Fate of cerebrospinal fluid-borne amyloid betapeptide: rapid clearance into blood and appreciable accumulation by cerebral arteries. J. Neurochem. 67, 880-883. doi: 10.1046/j.1471-4159.1996.670 20880.x
Ghiso, J., Shayo, M., Calero, M., Ng, D., Tomidokoro, Y., Gandy, S., et al. (2004). Systemic catabolism of Alzheimer's Abeta40 and Abeta42. J. Biol. Chem. 279, 45897-45908. doi: 10.1074/jbc.M407668200

Godoy, J. A., Zolezzi, J. M., Braidy, N., and Inestrosa, N. C. (2014). Role of sirt1 during the ageing process: relevance to protection of synapses in the brain. Mol. Neurobiol. doi: 10.1007/s12035-014-8645-5. [Epub ahead of print].

Gómez-Isla, T., Hollister, R., West, H., Mui, S., Growdon, J. H., Petersen, R. C., et al. (1997). Neuronal loss correlates with but exceeds neurofibrillary tangles in Alzheimer's disease. Ann. Neurol. 41, 17-24. doi: 10.1002/ana.410410106

Gouras, G. K., Tampellini, D., Takahashi, R. H., and Capetillo-Zarate, E. (2010). Intraneuronal $\beta$-amyloid accumulation and synapse pathology in Alzheimer's disease. Acta Neuropathol. 119, 523-541. doi: 10.1007/s00401-010-0679-9

Grimm, M. O., Mett, J., Stahlmann, C. P., Haupenthal, V. J., Zimmer, V. C., and Hartmann, T. (2013). Neprilysin and A $\beta$ clearance: impact of the APP intracellular domain in NEP regulation and implications in Alzheimer's disease. Front. Aging Neurosci. 5:98. doi: 10.3389/fnagi.2013.00098

Gronemeyer, H., Gustafsson, J. A., and Laudet, V. (2004). Principles for modulation of the nuclear receptor superfamily. Nat. Rev. Drug Discov. 3, 950-964. doi: 10. 1038/nrd1551

Guo, L., LaDu, M. J., and Van Eldik, L. J. (2004). A dual role for apolipoprotein e in neuroinflammation: anti- and pro-inflammatory activity. J. Mol. Neurosci. 23, 205-212. doi: 10.1385/jmn:23:3:205

Haass, C., and Selkoe, D. J. (2007). Soluble protein oligomers in neurodegeneration: lessons from the Alzheimer's amyloid beta-peptide. Nat. Rev. Mol. Cell Biol. 8, 101-112. doi: 10.1038/nrm2101

Haemmerle, G., Moustafa, T., Woelkart, G., Büttner, S., Schmidt, A., van de Weijer, T., et al. (2011). ATGL-mediated fat catabolism regulates cardiac mitochondrial function via PPAR- $\alpha$ and PGC-1 $\alpha$. Nat. Med. 17, 1076-1085. doi: 10.1038/nm. 2439

Hagland, H. R., Nilsson, L. I., Burri, L., Nikolaisen, J., Berge, R. K., and Tronstad, K. J. (2013). Induction of mitochondrial biogenesis and respiration is associated with mTOR regulation in hepatocytes of rats treated with the pan-PPAR activator tetradecylthioacetic acid (TTA). Biochem. Biophys. Res. Commun. 430, 573-578. doi: 10.1016/j.bbrc.2012.11.111

Haskew-Layton, R. E., Payappilly, J. B., Xu, H., Bennett, S. A., and Ratan, R. R. (2013). 15-Deoxy- $\Delta$ 12,14-prostaglandin J2 (15d-PGJ2) protects neurons from oxidative death via an Nrf2 astrocyte-specific mechanism independent of PPAR $\gamma$. J. Neurochem. 124, 536-547. doi: 10.1111/jnc.12107

Hawkes, C. A., Shaw, J. E., Brown, M., Sampson, A. P., McLaurin, J., and Carare, R. O. (2014). MK886 reduces cerebral amyloid angiopathy severity in TgCRND8 mice. Neurodegener. Dis. 13, 17-23. doi: 10.1159/000351096

Heinäniemi, M., Uski, J. O., Degenhardt, T., and Carlberg, C. (2007). Meta-analysis of primary target genes of peroxisome proliferator-activated receptors. Genome Biol. 8:R147. doi: 10.1186/gb-2007-8-7-r147

Heneka, M. T., and Landreth, G. E. (2007). PPARs in the brain. Biochim. Biophys. Acta 1771, 1031-1045. doi: 10.1016/j.bbalip.2007.04.016

Hernanz, R., Martín, A., Pérez-Girón, J. V., Palacios, R., Briones, A. M., Miguel, M., et al. (2012). Pioglitazone treatment increases COX-2-derived prostacyclin production and reduces oxidative stress. Br. J. Pharmacol. 166, 1303-1319. doi: 10.1111/j.1476-5381.2012.01825.x

Hondares, E., Rosell, M., Díaz-Delfin, J., Olmos, Y., Monsalve, M., Iglesias, R., et al. (2011). Peroxisome proliferator-activated receptor $\alpha(\operatorname{PPAR} \alpha)$ induces PPAR $\gamma$ coactivator $1 \alpha$ (PGC-1 $\alpha)$ gene expression and contributes to thermogenic activation of brown fat: involvement of PRDM16. J. Biol. Chem. 286, 4311243122. doi: 10.1074/jbc.M111.252775

Hoque, M. T., Robillard, K. R., and Bendayan, R. (2012). Regulation of breast cancer resistant protein by peroxisome proliferator-activated receptor $\alpha$ in human brain microvessel endothelial cells. Mol. Pharmacol. 81, 598-609. doi: 10.1124/mol. 111.076745

Inestrosa, N. C., Carvajal, F. J., Zolezzi, J. M., Tapia-Rojas, C., Serrano, F., Karmelic, D., et al. (2012). Peroxisome proliferators reduce spatial memory impairment, synaptic failure and neurodegeneration in brains of a double transgenic mice model of Alzheimer's disease. J. Alzheimers Dis. 33, 941-959. doi: 10.3233/JAD2012-120397

Inestrosa, N. C., Godoy, J. A., Quintanilla, R. A., Koenig, C. S., and Bronfman, M. (2005). Peroxisome proliferator-activated receptor gamma is expressed in hippocampal neurons and its activation prevents $\beta$-amyloid neurodegeneration: role of Wnt signaling. Exp. Cell Res. 304, 91-104. doi: 10.1016/j.yexcr.2004. 09.032 
Inestrosa, N. C., Godoy, J. A., Vargas, J. Y., Arrazola, M. S., Rios, J. A., Carvajal, F. J., et al. (2013). Nicotine prevents synaptic impairment induced by amyloid- $\beta$ oligomers through $\alpha 7$-nicotinic acetylcholine receptor activation. Neuromolecular Med. 15, 549-569. doi: 10.1007/s12017-013-8242-1

Inestrosa, N. C., and Toledo, E. M. (2008). The role of Wnt signaling in neuronal dysfunction in Alzheimer's disease. Mol. Neurodegener. 3:9. doi: 10.1186/17501326-3-9

Ito, S., Ueno, T., Ohtsuki, S., and Terasaki, T. (2010). Lack of brain-to-blood efflux transport activity of low-density lipoprotein receptor-related protein-1 (LRP-1) for amyloid- $\beta$ peptide (1-40) in mouse: involvement of an LRP-1-independent pathway. J. Neurochem. 113, 1356-1363. doi: 10.1111/j.1471-4159.2010. 06708.x

Iwaisako, K., Haimerl, M., Paik, Y. H., Taura, K., Kodama, Y., Sirlin, C., et al. (2012). Protection from liver fibrosis by a peroxisome proliferator-activated receptor $\delta$ agonist. Proc. Natl. Acad. Sci. U S A 109, E1369-E1376. doi: 10.1073/pnas. 1202464109

Jaeger, L. B., Dohgu, S., Hwang, M. C., Farr, S. A., Murphy, M. P., Fleegal-DeMotta, M. A., et al. (2009). Testing the neurovascular hypothesis of Alzheimer's disease: LRP-1 antisense reduces blood-brain barrier clearance, increases brain levels of amyloid- $\beta$ protein and impairs cognition. J. Alzheimers Dis. 17, 553-570. doi: 10. 3233/JAD-2009-1074

Jiang, S., Li, Y., Zhang, X., Bu, G., Xu, H., and Zhang, Y. (2014). Trafficking regulation of proteins in Alzheimer's disease. Mol. Neurodegener. 9:6. doi: 10. 1186/1750-1326-9-6

Kalinin, S., Richardson, J. C., and Feinstein, D. L. (2009). A PPARdelta agonist reduces amyloid burden and brain inflammation in a transgenic mouse model of Alzheimer's disease. Curr. Alzheimer Res. 6, 431-437. doi: 10. 2174/156720509789207949

Kanehisa, M., and Goto, S. (2000). KEGG: kyoto encyclopedia of genes and genomes. Nucleic Acids Res. 28, 27-30. doi: 10.1002/(sici)1097-0061(200004)17 $: 1<48$ ::aid-yea2>3.0.co;2-h

Kanehisa, M., Goto, S., Sato, Y., Kawashima, M., Furumichi, M., and Tanabe, M. (2014). Data, information, knowledge and principle: back to metabolism in KEGG. Nucleic Acids Res. 42, D199-D205. doi: 10.1093/nar/gkt1076

Kanekiyo, T., Liu, C., Shinohara, M., Li, J., and Bu, G. (2012). LRP1 in brain vascular smooth muscle cells mediates local clearance of Alzheimer's amyloid- $\beta$. J. Neurosci. 32, 16458-16465. doi: 10.1523/JNEUROSCI.3987-12.2012

Kapoor, A., Hsu, W. M., Wang, B. J., Wu, G. H., Lin, T. Y., Lee, S. J., et al. (2010). Caveolin-1 regulates $\gamma$-secretase-mediated A $\beta P P$ processing by modulating spatial distribution of $\gamma$-secretase in membrane. J. Alzheimers Dis. 22, 423-442. doi: 10.3233/JAD-2010-100531

Karran, E., Mercken, M., and De Strooper, B. (2011). The amyloid cascade hypothesis for Alzheimer's disease: an appraisal for the development of therapeutics. Nat. Rev. Drug Discov. 10, 698-712. doi: 10.1038/nrd3505

Kinoshita, A., Fukumoto, H., Shah, T., Whelan, C. M., Irizarry, M. C., and Hyman, B. T. (2003). Demonstration by FRET of BACE interaction with the amyloid precursor protein at the cell surface and in early endosomes. J. Cell Sci. 116, 3339-3346. doi: 10.1242/jcs.00643

Kröller-Schön, S., Jansen, T., Schüler, A., Oelze, M., Wenzel, P., Hausding, M., et al. (2013). Peroxisome proliferator-activated receptor $\gamma$, coactivator $1 \alpha$ deletion induces angiotensin II-associated vascular dysfunction by increasing mitochondrial oxidative stress and vascular inflammation. Arterioscler. Thromb. Vasc. Biol. 33, 1928-1935. doi: 10.1161/ATVBAHA.113.301717

LaClair, K. D., Manaye, K. F., Lee, D. L., Allard, J. S., Savonenko, A. V., Troncoso, J. C., et al. (2013). Treatment with bexarotene, a compound that increases apolipoprotein-E, provides no cognitive benefit in mutant APP/PS1 mice. Mol. Neurodegener. 8:18. doi: 10.1186/1750-1326-8-18

Lacor, P. N., Buniel, M. C., Chang, L., Fernandez, S. J., Gong, Y., Viola, K. L., et al. (2004). Synaptic targeting by Alzheimer's-related amyloid beta oligomers. J. Neurosci. 24, 10191-10200. doi: 10.1523/jneurosci.3432-04.2004

LaDu, M. J., Reardon, C., Van Eldik, L., Fagan, A. M., Bu, G., Holtzman, D., et al. (2000). Lipoproteins in the central nervous system. Ann. N Y Acad. Sci. 903, 167-175. doi: 10.1111/j.1749-6632-2000.tb06365.x

LaFerla, F. M. (2012). Preclinical success against Alzheimer's disease with an old drug. N. Engl. J. Med. 367, 570-574. doi: 10.1056/NEJMCibr1204890

LaFerla, F. M., Green, K. N., and Oddo, S. (2007). Intracellular amyloid- $\beta$ in Alzheimer's disease. Nat. Rev. Neurosci. 8, 499-509. doi: 10.1038/nrn2168

Landreth, G. E., Cramer, P. E., Lakner, M. M., Cirrito, J. R., Wesson, D. W., Brunden, K. R., et al. (2013). Response to comments on "ApoE-directed therapeutics rapidly clear $\beta$-amyloid and reverse deficits in AD mouse models". Science 340:924. doi: 10.1126/science. 1234114

Lane, R. F., Shineman, D. W., Steele, J. W., Lee, L. B., and Fillit, H. M. (2012). Beyond amyloid: the future of therapeutics for Alzheimer's disease. Adv. Pharmacol. 64, 213-271. doi: 10.1016/B978-0-12-394816-8.00007-6

Langbaum, J. B., Fleisher, A. S., Chen, K., Ayutyanont, N., Lopera, F., Quiroz, Y. T., et al. (2013). Ushering in the study and treatment of preclinical Alzheimer disease. Nat. Rev. Neurol. 9, 371-381. doi: 10.1038/nrneurol.20 13.107

Larner, A. J. (2013). Presenilin-1 mutations in Alzheimer's disease: an update on genotype-phenotype relationship. J. Alzheimers Dis. 37, 653-659. doi: 10. 3233/JAD-130746

Lesné, S. E., Sherman, M. A., Grant, M., Kuskowski, M., Schneider, J. A., Bennett, D. A., et al. (2013). Brain amyloid- $\beta$ oligomers in ageing and Alzheimer's disease. Brain 136, 1383-1398. doi: 10.1093/brain/awt062

Li, J., Kanekiyo, T., Shinohara, M., Zhang, Y., LaDu, M. J., Xu, H., et al. (2012). Differential regulation of amyloid- $\beta$ endocytic trafficking and lysosomal degradation by apolipoprotein E isoforms. J. Biol. Chem. 287, 44593-44601. doi: 10. 1074/jbc.M112.420224

Li, S., Shankar, G. M., and Selkoe, D. J. (2010). How do soluble oligomers of amyloid beta-protein impair hippocampal synaptic plasticity? Front. Cell. Neurosci. 4:5. doi: 10.3389/fncel.2010.00005

Li, R., Wang, Y., Liu, Y., Chen, Q., Fu, W., Wang, H., et al. (2013). Curcumin inhibits transforming growth factor- $\beta 1$-induced EMT via PPAR $\gamma$ pathway, not Smad pathway in renal tubular epithelial cells. PLoS One 8:e58848. doi: 10. 1371/journal.pone.0058848

Liebner, S., and Plate, K. H. (2010). Differentiation of the brain vasculature: the answer came blowing by the Wnt. J. Angiogenes. Res. 2:1. doi: 10.1186/20402384-2-1

Liu, M., Liang, Y., Chiqurupati, S., Lathia, J. D., Pletnikov, M., Sun, Z., et al. (2008). Acute kidney injury leads to inflammation and functional changes in the brain. J. Am. Soc. Nephrol. 19, 1360-1370. doi: 10.1681/ASN.2007080901

Lutz, W., Sanderson, W., and Scherbov, S. (2008). The coming acceleration of global population ageing. Nature 451, 716-719. doi: 10.1038/nature06516

Mandrekar-Colucci, S., Karlo, J. C., and Landreth, G. E. (2012). Mechanisms underlying the rapid peroxisome proliferator-activated receptor- $\gamma$-mediated amyloid clearance and reversal of cognitive deficits in a murine model of Alzheimer's disease. J. Neurosci. 32, 10117-10128. doi: 10.1523/JNEUROSCI.5268-11. 2012

Manji, H., Kato, T., Di Prospero, N. A., Ness, S., Beal, M. F., Krams, M., et al. (2012). Impaired mitochondrial function in psychiatric disorders. Nat. Rev. Neurosci. 13, 293-307. doi: 10.1038/nrn3229

Marquer, C., Devauges, V., Cossec, J. C., Liot, G., Lécart, S., Saudou, F., et al. (2011). Local cholesterol increase triggers amyloid precursor protein-BACE1 clustering in lipid rafts and rapid endocytosis. FASEB J. 25, 1295-1305. doi: 10.1096/fj. 10-168633

Martín, A., Pérez-Girón, J. V., Hernanz, R., Palacios, R., Briones, A. M., Fortuño, A., et al. (2012). Peroxisome proliferator-activated receptor- $\gamma$ activation reduces cyclooxygenase- 2 expression in vascular smooth muscle cells from hypertensive rats by interfering with oxidative stress. J. Hypertens. 30, 315-326. doi: 10. 1097/HJH.0b013e32834f043b

Mizuguchi, M., Ikeda, K., and Kim, S. U. (1992). Differential distribution of cellular forms of $\beta$-amyloid precursor protein in murine glial cell cultures. Brain Res. 584, 219-225. doi: 10.1016/0006-8993(92)90898-j

Mok, K. Y., Jones, E. L., Hanney, M., Harold, D., Sims, R., Williams, J., et al. (2013). Polymorphisms in BACE2 may affect the age of onset Alzheimer's dementia in down syndrome. Neurobiol. Aging 35, 1513.e1-1513.e5. doi: 10. 1016/j.neurobiolaging.2013.12.022

Morgan, L., Shah, B., Rivers, L. E., Barden, L., Groom, A. J., Chung, R., et al. (2007). Inflammation and dephosphorylation of the tight junction protein occluding in an experimental model of multiple sclerosis. Neuroscience 147, 664-673. doi: 10. 1016/j.neuroscience.2007.04.051

Mroczko, B., Groblewska, M., and Barcikowska, M. (2013). The role of matrix metalloproteinases and tissue inhibitors of metalloproteinases in the pathophysiology of neurodegeneration: a literature study. J. Alzheimers Dis. 37, 273-283. doi: 10.3233/JAD-130647

Mucke, L., and Selkoe, D. J. (2012). Neurotoxicity of amyloid $\beta^{2}$-protein: synaptic and network dysfunction. Cold Spring Harb. Perspect. Med. 2:a006338. doi: 10. $1101 /$ cshperspect.a006338 
Mulholland, D. J., Dedhar, S., Coetzee, G. A., and Nelson, C. C. (2005). Interaction of nuclear receptors with the Wnt/ $\beta$-catenin/Tcf signaling axis: Wnt you like to know? Endocr. Rev. 26, 898-915. doi: 10.1210/er.2003-0034

Mysiorek, C., Culot, M., Dehouck, L., Derudas, B., Bordet, R., Cecchelli, R., et al. (2009). Peroxisome proliferator-activated receptor-alpha activation protects brain capillary endothelial cells from oxygen-glucose deprivation-induced hyperpermeability in the blood-brain barrier. Curr. Neurovasc. Res. 6, 181-193. doi: 10.2174/156720209788970081

Näslund, J., Haroutunian, V., Mohs, R., Davis, K. L., Davies, P., Greengard, P., et al. (2000). Correlation between elevated levels of amyloid $\beta$-peptide in the brain and cognitive decline. JAMA 283, 1571-1577. doi: 10.1001/jama.283. 12.1571

Natunen, T., Parrado, A. R., Helisalmi, S., Pursiheimo, J. P., Sarajärvi, T., Mäkinen, P., et al. (2013). Elucidation of the BACE1 regulating factor GGA3 in Alzheimer's disease. J. Alzheimers Dis. 37, 217-232. doi: 10.3233/JAD-130104

Neher, M. D., Weckbach, S., Huber-Lang, M. S., and Stahel, P. F. (2012). New insights into the role of peroxisome proliferator-activated receptors in regulating the inflammatory response after tissue injury. PPAR Res. 2012:728461. doi: 10. $1155 / 2012 / 728461$

Nenov, M. N., Laezza, F., Haidacher, S. J., Zhao, Y., Sadygov, R. G., Starkey, J. M., et al. (2014). Cognitive enhancing treatment with a PPAR $\gamma$ agonist normalizes dentate granule cell presynaptic function in Tg2576 APP mice. J. Neurosci. 34, 1028-1036. doi: 10.1523/jneurosci.3413-13.2014

Nicolakakis, N., Aboulkassim, T., Ongali, B., Lecrux, C., Fernandes, P., RosaNeto, P., et al. (2008). Complete rescue of cerebrovascular function in aged Alzheimer's disease transgenic mice by antioxidants and pioglitazone, a peroxisome proliferator-activated receptor gamma agonist. J. Neurosci. 28, 9287-9296. doi: 10.1523/jneurosci.3348-08.2008

Nilsson, P., and Saido, T. C. (2014). Dual roles for autophagy: degradation and secretion of Alzheimer's disease A $\beta$ peptide. Bioessays 36, 570-578. doi: 10. 1002/bies.201400002

Nixon, R. A., Mathews, P. M., and Cataldo, A. M. (2001). The neuronal endosomallysosomal system in Alzheimer's disease. J. Alzheimers Dis. 3, 97-107.

Olefsky, J. M. (2001). Nuclear receptor minireview series. J. Biol. Chem. 276, 3686336864. doi: 10.1074/jbc.r100047200

Oliva, C. A., Vargas, J. Y., and Inestrosa, N. C. (2013). Wnt signaling: role in LTP, neural networks and memory. Ageing Res. Rev. 12, 786-800. doi: 10.1016/j.arr. 2013.03.006

Papadopoulos, P., Rosa-Neto, P., Rochford, J., and Hamel, E. (2013). Pioglitazone improves reversal learning and exerts mixed cerebrovascular effects in a mouse model of Alzheimer's disease with combined amyloid- $\beta$ and cerebrovascular pathology. PLoS One 8:e68612. doi: 10.1371/journal.pone.0068612

Pascale, C. L., miller, M. C., Chiu, C., Boylan, M., Caralopoulos, I. N., Gonzales, L., et al. (2011). Amyloid-beta transporter expression at the blood-CSF barrier isa ge-dependent. Fluids Barriers CNS 8:21. doi: 10.1186/2045-8118-8-21

Patterson, A. D., Shah, Y. M., Matsubara, T., Krausz, K. W., and Gonzales, F. J. (2012). Peroxisome proliferator-activated receptor alpha induction of uncoupling protein 2 protects against acetaminophen-induced liver toxicity. Hepatology 56, 281-290. doi: 10.1002/hep. 25645

Paula-Lima, A. C., Adasme, T., SanMartin, C., Sebollela, A., Hetz, C., Carrasco, M. A., et al. (2011). Amyloid b-peptide oligomers stimulate RyR-mediated $\mathrm{Ca}^{2+}$ release inducing mitocondrial fragmentation in hippocampal neurons and prevent RyR-mediated dendritic spine remodeling produced by BDNF. Antioxid. Redox Signal. 14, 1209-1223. doi: 10.1089/ars.2010.3287

Perl, D. P. (2010). Neuropathology of Alzheimer's disease. Mt. Sinai J. Med. 77, 32 42. doi: $10.1002 / \mathrm{msj} .20157$

Pipatpiboon, N., Pratchayasakul, W., Chattipakorn, N., and Chattipakorn, S. C. (2012). PPAR $\gamma$ agonist improves neuronal insulin receptor function in hippocampus and brain mitochondria function in rats with insulin resistance induced by long term high-fat diets. Endocrinology 153, 329-338. doi: 10 . 1210/en.2011-1502

Popa-Wagner, A., Buga, A. M., and Kokaia, Z. (2011). Perturbed cellular response to brain injury during aging. Ageing Res. Rev. 10, 71-79. doi: 10.1016/j.arr.2009. 10.008

Popa-Wagner, A., Buga, A. M., Popescu, B., and Muresanu, D. (2013). Vascular cognitive impairment, dementia, aging and energy demand. A vicious cycle. $J$. Neural. Transm. doi: 10.1007/s00702-013-1129-3. [Epub ahead of print].

Price, A. R., Xu, G., Siemienski, Z. B., Smithson, L. A., Borchelt, D. R., Golde, T. E., et al. (2013). Comment on "ApoE-directed therapeutics rapidly clear $\beta$-amyloid and reverse deficits in AD mouse models". Science 340:924. doi: 10.1126/science. 1234089

Priller, C., Bauer, T., Mitteregger, G., Krebs, B., Kretzschmar, H. A., and Herms, J. (2006). Synapse formation and function is modulated by the amyloid precursor protein. J. Neurosci. 26, 7212-7221. doi: 10.1523/jneurosci.1450-06.2006

Quintanilla, R. A., Godoy, J. A., Alfaro, I., Cabezas, D., von Bernhardi, R., Bronfman, M., et al. (2013). Thiazolidinediones promote axonal growth through the activation of the JNK pathway. PLoS One 8:e65140. doi: 10. 1371/journal.pone.0065140

Ryan, L. (2014). Update on Alzheimer's disease clinical trials. National institutes on aging (NIA), national institutes of health (NIH), on national Alzheimer's coordinating center (NACC). Available online at: https://www.alz.washington.edu/ NONMEMBER/SPR12/Ryan.pdf. Accessed February 17th, 2014.

Sagare, A. P., Deane, R., and Zlokovic, B. V. (2012). Low-density lipoprotein receptor-related protein 1: a physiological $A \beta$ homeostatic mechanism with multiple therapeutic opportunities. Pharmacol. Ther. 136, 94-105. doi: 10. 1016/j.pharmthera.2012.07.008

Sagare, A., Deane, R., Bell, R. D., Johnson, B., Hamm, K., Pendu, R., et al. (2007). Clearance of amyloid-beta by circulating lipoprotein receptors. Nat. Med. 13, 1029-1031. doi: 10.3410/f.1091075.54446

Sagare, A. P., Winkler, E. A., Bell, R. D., Deane, R., and Zlokovic, B. V. (2011). From the liver to the blood-brain barrier: an interconnected system regulating brain amyloid- $\beta$ levels. J. Neurosci. Res. 89, 967-968. doi: 10.1002/jnr.22670

Salmon, D. P., and Bondi, M. W. (2009). Neuropsychological assessment of dementia. Annu. Rev. Psychol. 60, 257-282. doi: 10.1146/annurev.psych.57.102904. 190024

Santos, M. J., Quintanilla, R. A., Toro, A., Grandy, R., Dinamarca, M. C., Godoy, J. A., et al. (2005). Peroxisomal proliferation protects from $\beta$-amyloid neurodegeneration. J. Biol. Chem. 280, 41057-41068. doi: 10.1074/jbc.m5051 60200

Savva, G. M., Wharton, S. B., Ince, P. G., Forster, G., Matthews, F. E., and Brayne, C. (2009). Age, neuropathology and dementia. N. Engl. J. Med. 360, 2302-2309. doi: 10.1056/NEJMoa0806142

Scheff, S. W., Price, D. A., Schmitt, F. A., DeKosky, S. T., and Mufson, E. J. (2007). Synaptic alterations in CA1 in mild Alzheimer disease and mild cognitive impairment. Neurology 68, 1501-1508. doi: 10.1212/01.wnl.0000260698. 46517.8f

Selkoe, D. J. (2001). Alzheimer's disease results from the cerebral accumulation and cytotoxicity of amyloid beta-protein. J. Alzheimers Dis. 3, 75-80.

Serrano-Pozo, A., Frosch, M. P., Masliah, E., and Hyman, B. T. (2011). Neuropathological alterations in Alzheimer disease. Cold Spring Harb. Perspect. Biol. 1:a006189. doi: 10.1101/cshperspect.a006189

Shaerzadeh, F., Motamedi, F., Minai-Tehrani, D., and Khodagholi, F. (2014). Monitoring of neuronal loss in the hippocampus of $A \beta$-injected rat: autophagy, mitophagy and mitochondrial biogenesis stand against apoptosis. Neuromolecular Med. 16, 175-190. doi: 10.1007/s12017-013-8272-8

Shea, Y. F., Chu, L. W., Mok, M. Y., and Lam, M. F. (2014). Amyloid beta 142 and tau in the cerebrospinal fluid of renal failure patients for the diagnosis of Alzheimer's disease. J. Nephrol. 27, 217-220. doi: 10.1007/s40620-0140043-6

Sheng, M., Sabatini, B. L., and Südhof, T. C. (2012). Synapses and Alzheimer's disease. Cold Spring Harb. Perspect. Biol. 4:a005777. doi: 10.1101/cshperspect. a005777

Silva, D. F., Selfridge, J. E., Lu, J., E, L., Roy, N., Hutfles, L., et al. (2013). Bioenergetics flux, mitochondrial mass and mitochondrial morphology dynamics and AD and MCI cybrid cell lines. Hum. Mol. Genet. 22, 3931-3946. doi: 10. 1093/hmg/ddt247

Silva-Alvarez, C., Arrázola, M. S., Godoy, J. A., Ordenes, D., and Inestrosa, N. C. (2013). Canonical Wnt signaling protects hippocampal neurons from $\mathrm{A} \beta$ oligomers: role of non-canonical Wnt-5a/Ca(2+) in mitocondrial dynamics. Front. Cell Neurosci. 7:97. doi: 10.3389/fncel.2013.00097

Singh, I., Sagare, A. P., Coma, M., Perlmutter, D., Gelein, R., Bell, R. D., et al. (2013). Low levels of copper disrupt brain amyloid- $\beta$ homeostasis by altering its production and clearance. Proc. Natl. Acad. Sci. U S A 110, 14771-14776. doi: 10.1073/pnas.1302212110

Südhof, T. C. (2012). The presynaptic active zone. Neuron 75, 11-25. doi: 10.1016/j. neuron.2012.06.012

Südhof, T. C. (2013). Neurotransmitter release: the last millisecond in the life of a synaptic vesicle. Neuron 80, 675-690. doi: 10.1016/j.neuron.2013.10.022 
Tai, L. M., Mehra, S., Shete, V., Estus, S., Rebeck, G. W., Bu, G., et al. (2014). Soluble apoE/A $\beta$ complex: mechanism and therapeutic target for APOE4-induced AD risk. Mol. Neurodegener. 9:2. doi: 10.1186/1750-1326-9-2

Tamaki, C., Ohtsuki, S., Iwatsubo, T., Hashimoto, T., Yamada, K., Yabuki, C., et al. (2006). Major involvement of low-density lipoprotein receptor-related protein-1 in the clearance of plasma free amyloid betapeptide by the liver. Pharm. Res. 23, 1407-1416. doi: 10.1007/s11095-006-0208-7

Tamaki, C., Ohtsuki, S., and Terasaki, T. (2007). Insulin facilitates the hepatic clearance of plasma amyloid beta-peptide (1-40) by intracellular translocation of low-density lipoprotein receptor-related protein 1 (LRP-1) to the plasma membrane in hepatocytes. Mol. Pharmacol. 72, 850-855. doi: 10.1124/mol.107. 036913

Tampellini, D., Rahman, N., Lin, M. T., Capetillo-Zarate, E., and Gouras, G. K. (2011). Impaired $\beta$-amyloid secretion in Alzheimer's disease pathogenesis. $J$. Neurosci. 31, 15384-15390. doi: 10.1523/JNEUROSCI.2986-11.2011

Tesseur, I., Lo, A. C., Roberfroid, A., Dietvorst, S., Van Broeck, B., Borgers, M., et al. (2013). Comment on "ApoE-directed therapeutics rapidly clear $\beta$-amyloid and reverse deficits in AD mouse models". Science 340:924. doi: 10.1126/science. 1233937

Toledo, E. M., and Inestrosa, N. C. (2010). Activation of Wnt signaling by lithium and rosiglitazone reduced spatial memory impairment and Neurodegeneration in brains of an APPswe/PSEN1DeltaE9 mouse model of Alzheimer's disease. Mol. Psychiatry 15, 272-285. doi: 10.1038/mp.2009.72

Turner, P. R., O'Connor, K., Tate, W.P., and Abraham, W. C. (2003). Roles of amyloid precursor protein and its fragments in regulating neural activity, plasticity and memory. Prog. Neurobiol. 70, 1-32. doi: 10.1016/s0301-0082(03) 00089-3

Ureshino, R. P., Rocha, K. K., Lopes, G. S., Bincoletto, C., and Smaili, S. S. (2014). Calcium signaling alterations, oxidative stress and autophagy in aging. Antioxid. Redox Signal. 21, 123-137. doi: 10.1089/ars.2013.5777

Vásquez, M. C., Vargas, L. M., Inestrosa, N. C., and Alvarez, A. R. (2009). c-Abl modulates AICD dependent cellular responses: transcriptional induction and apoptosis. J. Cell Physiol. 220, 136-143. doi: 10.1002/jcp.21743

Veeraraghavalu, K., Zhang, C., Miller, S., Hefendehl, J. K., Rajapaksha, T. W., Ulrich, J., et al. (2013). Comment on "ApoE-directed therapeutics rapidly clear $\beta$-amyloid and reverse deficits in AD mouse models". Science 340:924. doi: 10 1126/science. 1235505

Wang, R., Li, J. J., Diao, S., Kwak, Y. D., Liu, L., Zhi, L., et al. (2013). Metabolic stress modulates Alzheimer's $\beta$-secretase gene transcription via SIRT1-PPAR $\gamma$-PGC-1 in neurons. Cell Metab. 17, 685-694. doi: 10.1016/j.cmet.2013.03.016

Xu, H., Greengard, P., and Gansy, S. (1995). Regulated formation of Golgi secretory vesicles containing Alzheimer $\beta$-amyloid precursor protein. J. Biol. Chem. 270, 23243-23245. doi: 10.1074/jbc.270.40.23243

Yamanaka, M., Ishikawa, T., Griep, A., Axt, D., Kummer, M. P., and Heneka, M. T. (2012). PPAR $\gamma / R X R \alpha$-induced and CD36-mediated microglial amyloid$\beta$ phagocytosis results in cognitive improvement in amyloid precursor protein/presenilin 1 mice. J. Neurosci. 32, 17321-17331. doi: 10.1523/JNEUROSCI. 1569-12.2012

Yan, R., and Vassar, R. (2014). Targeting the $\beta$ secretase BACE1 for Alzheimer's disease therapy. Lancet Neurol. 13, 319-329. doi: 10.1016/S1474-4422(13) 70276-X

Yang, Y., Duan, W., Li, Y., Yan, J., Yi, W., Liang, Z., et al. (2013). New role of silent information regulator 1 in cerebral ischemia. Neurobiol. Aging 34, 2879-2888. doi: 10.1016/j.neurobiolaging.2013.06.008

Zarzuelo, M. J., Gómez-Guzmán, M., Jiménez, R., Quintela, A. M., Romero, M., Sánchez, M., et al. (2013). Effects of peroxisome proliferator-activated receptor$\beta$ activation in endothelin-dependent hypertension. Cardiovasc. Res. 99, 622631. doi: $10.1093 / \mathrm{cvr} / \mathrm{cvt} 152$

Zhang, H. L., Xu, M., Wei, C., Qin, A. P., Liu, C. F., Hong, L. Z., et al. (2011). Neuroprotective effects of pioglitazone in a rat model of permanent focal cerebral ischemia are associated with peroxisome proliferator-activated receptor gamma-mediated suppression of nuclear factor- $\kappa \mathrm{B}$ signaling pathway. Neuroscience 176, 381-395. doi: 10.1016/j.neuroscience.2010.12.029

Zheng, H., and Koo, E. H. (2006). The amyloid precursor protein: beyond amyloid. Mol. Neurodegener. 1:5. doi: 10.1186/1750-1326-1-5

Zheng, L., Cedazo-Minguez, A., Hallbeck, M., Jerhammar, F., Marcusson, J., and Terman, A. (2012). Intracellular distribution of amyloid beta peptide and its relationship to the lysosomal system. Transl. Neurodegener. 1:19. doi: 10 . 1186/2047-9158-1-19

Zhou, W., Cai, F., Li, Y., Yang, G. S., O’Connor, K. D., Holt, R. A., et al. (2010). BACE1 gene promoter single-nucleotide polymorphisms in Alzheimer's disease. J. Mol. Neurosci. 42, 127-133. doi: 10.1007/s12031-010-9381-6

Zhou, Y., Luo, P., Chang, H. H., Huang, H., Yang, T., Dong, Z., et al. (2008). Clofibrate attenuates blood pressure and sodium retention in DOCA-salt hypertension. Kidney Int. 74, 1040-1048. doi: 10.1038/ki.2008.300

Zhu, Y., Nwabuisi-Heath, E., Dumanis, S. B., Tai, L. M., Yu, C., Rebeck, G. W., et al. (2012). APOE genotype alters glial activation and loss of synaptic markers in mice. Glia 60, 559-569. doi: 10.1002/glia.22289

Zlokovic, B. V. (2010). Neurodegeneration and the vascular unit. Nat. Med. 16, 1370-1371. doi: 10.1038/nm1210-1370

Zlokovic, B. V. (2011). Neurovascular pathways to neurodegeneration in Alzheimer's disease and other disorders. Nat. Rev. Neurosci. 12, 723-738. doi: 10. 1038/nrn3114

Zlokovic, B. V., Deane, R., Sagare, A. P., Bell, R. D., and Winkler, E. A. (2010). Lowdensity lipoprotein receptor-related protein-1: a serial clearance homeostatic mechanism controlling Alzheimer's amyloid $\beta$-peptide elimination from the brain. J. Neurochem. 115, 1077-1089. doi: 10.1111/j.1471-4159.2010.07002.x

Zolezzi, J. M., Carvajal, F. J., Ríos, J. A., Ordenes, D., Silva-Alvarez, C., Godoy, J. A., et al. (2013b). Tetrahydrohyperforin induces mitochondrial dynamics and prevents mitochondrial Ca2+ overload after $\mathrm{A} \beta$ and $\mathrm{A} \beta$-AChE complex challenge in rat hippocampal neurons. J. Alzheimers Dis. 37, 735-746. doi: 10. 3233/JAD-130173

Zolezzi, J. M., and Inestrosa, N. C. (2013). Peroxisome proliferator-activated receptors and Alzheimer's disease: hitting the blood-brain barrier. Mol. Neurobiol. 48 , 438-451. doi: 10.1007/s12035-013-8435-5

Zolezzi, J. M., and Inestrosa, N. C. (2014). Brain metabolite clearance: impact on Alzheimer's disease. Metab. Brain Dis. doi: 10.1007/s11011-014-9527-2. [Epub ahead of print].

Zolezzi, J. M., Silva-Alvarez, C., Ordenes, D., Godoy, J. A., Carvajal, F. J., Santos, M. J., et al. (2013a). Peroxisome proliferator-activated receptor (PPAR) $\gamma$ and PPAR $\alpha$ agonists modulate mitochondrial fusion-fission dynamics: relevance to reactive oxygen species (ROS)-related neurodegenerative disorders? PLoS One 8:e64019. doi: 10.1371/journal.pone.0064019

Conflict of Interest Statement: The authors declare that the research was conducted in the absence of any commercial or financial relationships that could be construed as a potential conflict of interest.

Received: 03 April 2014; accepted: 03 July 2014; published online: 28 July 2014.

Citation: Zolezzi JM, Bastías-Candia S, Santos MJ and Inestrosa NC (2014) Alzheimer's disease: relevant molecular and physiopathological events affecting amyloid- $\beta$ brain balance and the putative role of PPARs. Front. Aging Neurosci. 6:176. doi: $10.3389 /$ fnagi.2014.00176

This article was submitted to the journal Frontiers in Aging Neuroscience.

Copyright (c) 2014 Zolezzi, Bastías-Candia, Santos and Inestrosa. This is an openaccess article distributed under the terms of the Creative Commons Attribution License (CC BY). The use, distribution or reproduction in other forums is permitted, provided the original author(s) or licensor are credited and that the original publication in this journal is cited, in accordance with accepted academic practice. No use, distribution or reproduction is permitted which does not comply with these terms. 